\title{
Etik Liderlik ile Bilgi Paylaşımı Arasındaki İlişki: Sistematik Bir İnceleme
}

(Derleme)

The Relationship Between Ethical Leadership and Knowledge Sharing: A

Systematic Review

Doi: 10.29023/alanyaakademik.806259

Yavuz Selim DÜGER

Dr. Öğr. Üyesi, Kütahya Dumlupınar Üniversitesi, İ̈BF, Uluslararası Ticaret ve Finans

yselim.duger@dpu.edu.tr

Orcid No:0000-0003-3523-9671

Bu makaleye atıfta bulunmak için: Düger, Y. S. (2021). "Etik Liderlik ile Bilgi Paylaşımı Arasındaki İlişki: Sistematik Bir Inceleme”, Alanya Akademik Bakış, 5(2), Sayfa No.619-645.

\section{Anahtar kelimeler: \\ Etik Liderlik, Bilgi \\ Paylaşımı, Sistematik \\ Inceleme}

Makale Geliş Tarihi:

06.10.2020

Kabul Tarihi:

05.04.2021

Keywords:

Ethical Leadership,

Knowledge Sharing,

Systematic Review

\section{ÖZET}

Bu çalışmada, etik liderliğin çalışanların bilgi paylaşımına olan etkisini kavramsal olarak ortaya koymak amaçlanmaktadır. Bu bağlamda, sistematik literatür incelemesi yapılmıştır. İncelemeler sonucunda, çalışanların bilgi paylaşımı davranışı sergilemesinde etik liderliğin güçlü etkilerinin olduğu belirlenmiştir. Ayrıca, detaylı literatür taraması sonucuna göre; lider-üye değişimi, örgütsel vatandaşlık davranışı, iş tatmini, öz-yeterlilik, lidere olan güven, algılanan örgütsel destek, içsel motivasyon, örgütsel bağlllık ve örgütsel özdeşleşme gibi bazı faktörlerin hem etik liderliğin çıktısı hem de bilgi paylaşımının öncülleri olduğu anlaşılmaktadır. Belirlenen bu ortak faktörler çerçevesinde literatürde yeterince ilişsi kurulmadĭg sonucuna ulaşılmışıır. Etik liderlik ile bilgi paylaşımı arasındaki ilişki, sosyal değişim teorisi, rol model teorisi, karşıllklllık teorisi, sosyal ögrenme teorisi vb. teoriler çerçevesinde ele alınmadiğg gözlemlenmektedir. Bununla birlikte, kültürel farklılıkların etik liderlik ile bilgi paylaşım davranışı arasındaki iliş̧iye olan muhtemel etkileri araştırmactlar tarafindan incelenmediği de görülmektedir.

\section{ABSTRACT}

In this study, it is aimed to reveal conceptually the effect of ethical leadership on knowledge sharing of employees. In this context, a systematic literature review has been conducted. As a result of the examination, it was determined that ethical leadership has strong effects on the formation of knowledge sharing. Also, according to the detailed literature review; it is come up that some factors such as leader-member exchange, organizational citizenship behavior, job satisfaction, self-efficacy, trust in the leader, perceived organizational support, intrinsic motivation, organizational commitment, and organizational identification are both the outcome of ethical leadership and the antecedents of knowledge sharing. It has been concluded that a sufficient correlation has not been established in the literature within the framework of these common factors. It is observed that the relationship between ethical leadership and knowledge sharing is not handled within the framework of such theories as social change theory, role model theory, reciprocity theory, 
social learning theory, etc. Moreover, it is seen that the possible effects of cultural differences on the relationship between ethical leadership and knowledge sharing behavior have not been investigated by researchers.

\section{GİRIŞ̧}

"Post-Modern Toplum", "Bilgi Toplumu", "Enformasyon Toplumu" veya "Dijital Toplum" gibi farklı kavramlarla adlandırılan günümüz bilgi çağı, toplumsal yaşam ve iş hayatında köklü değişikliklerin meydana geldiği bir dönemdir. Bu değişimin sonucunda üretim, yönetim, pazarlama ve liderlik anlayışları, gelişen bilgiye bağlı olarak sürekli yenilenmektedir. İşletmelerin bu ortamda hayatta kalabilmeleri, yeni firsatları yakalayabilmeleri ve rekabet avantajı elde edebilmeleri ancak bilgiyi yöneterek güncel kalmalarına bağlıdır. Bilgi yönetiminin başarısı ise büyük ölçüde çalışanların bilgi paylaşımına katılma motivasyonuna bağlıdır (Gagne, 2009: 572).

Bir işletmede bilgi akışının çok önemli olduğu bilinmesine rağmen, çalışanlar bilgiyi saklama eğilimindedir (Connelly vd., 2012: 64). Bu durum, organizasyonun genel başarısını olumsuz yönde etkilemektedir. Lin (2007a), çalışanların bilgiyi iş arkadaşlarıyla paylaşmayı reddetmelerinin, bir işletmenin sürdürebilirliği ve rekabet gücü gibi temel çıkarlarını tehdit ettiğini belirtmiş ve bu durumu ahlaki normların ihlali olarak değerlendirmiştir. Ayrıca, çalışanların bilgi paylaşımına eğilimli olmamaları, bir örgütün sosyal dokusuna, çalışanların ve işletmenin üretkenliği ve performansı üzerinde yıkıcı etkilere neden olabilmektedir (Zhao ve Xia, 2019: 357). Çalışanlar arasında bilgi paylaşımının yeterli düzeyde olmaması, kişiler arası güven ve ilişki dinamiklerini bozmakta, çalışanların öğrenme sürecini ve yaratıcılığını geliştirme stratejilerini tehlikeye atabilmektedir (Connelly vd, 2012: 65).

Liderler sahip oldukları vizyon ve değerler ile işletmenin örgütsel yapısını şekillendirir, çalışanlara rehberlik eder ve rol model olurlar. Liderin sergilemiş olduğu yaklaşımlar, alınan kararları, sahip olunan gücün kullanımını, işletmeyi ve çalışanları etkilemektedir. Özellikle liderlerin çalışanların tutum ve davranışlarını şekillendirme noktasında önemli bir etkisi vardır. Ayrıca, liderlerin çalışanların sahip olduğu bilgilerin paylaşımı ve akışını gerçekleştirebilecek bir örgüt kültürü oluşturulması ve bu bilgilerin örgütsel karar verme süreçlerine entegre edilmesi noktasında da önemli bir rolü vardır (Doğan ve Kılıç, 2009: 88). Bu nedenle, tüm çalışanlara eşit yaklaşan, dürüstlük, adalet, tarafsılılk gibi evrensel değerleri benimseyen bir liderlik davranışı, çalışanların olumlu tutum ve davranışlar sergilemesinde önemli katkısı olacaktır. Etik liderlik, diğer liderlik tarzlarına göre (karizmatik, dönüştürücü, otantik, hizmetkâr liderlik vb.) daha fazla ahlaki ve etik değerlere odaklanması nedeniyle ön plana çıkmaktadır (Fry ve Kriger, 2009: 1678).

Literatürde liderlik stilleri ile çalışanların bilgi paylaşımı arasındaki ilişkiye dair çoğu çalışma, dönüşümcü liderlik çerçevesinde ele alınmıştır. Bununla birlikte, son zamanlarda etik liderliğin çalışanların bilgi paylaşımına olan etkilerini ampirik olarak inceleyen çalışmalarında yapıldığ1 görülmektedir (Bavik vd., 2018; Bhatti vd., 2020; Le ve Lei, 2018; Ma vd. 2013; Masood, 2020; Shafique vd., 2019; Tang vd., 2015). Yerli literatürde ise etik liderlik davranışı ile çalışanların bilgi paylaşımı arasındaki ilişkiyi doğrudan konu alan herhangi bir çalışmaya rastlanılmamıştır. Bu çalışmanın amacı, yerli literatürdeki boşluğu doldurmak adına, kavramsal olarak etik liderlik davranışı ile çalışanların bilgi paylaşımı arasındaki ilişkiyi açıklamaktır. 


\section{YÖNTEM}

Bu çalışmada, araştırmaya konu olan kavramlar sistematik olarak incelenmiştir. İlk olarak etik liderliğin öncülleri araştırılmış, sonrasında etik liderliğin örgütsel davranışlara olan etkileri incelenmiş, daha sonra bilgi paylaşımının öncülleri ortaya konmuş ve son olarak etik liderlik ile bilgi paylaşımı arasındaki ilişkiyi konu alan araştırmalar sistematik olarak incelenerek sentezleme yapılmıştır. Literatür incelemesinde, Brown vd. (2005) geliştirdiği etik liderlik modeli ve Connelly vd. (2012), Hsu vd. (2007), van den Hooff ve de Ridder (2004), Wang ve Wang (2012) geliştirdiği bilgi paylaşım modelleri doğrultusunda araştırma yapılmıştır.

Literatür taramasında, Moher vd. (2009) tarafindan geliştirilen PRISMA (Preferred Reporting Items for Systematic Reviews and Meta-Analyses) klavızı temel hatlarıyla kullanılmıştır. Bu bağlamda, arama stratejisi, dâhil etme ve hariç tutma ölçütleri, çalışmaların seçimi, verilerin çıkartılması ve veri analizi/sentezi aşamaları kullanılmıştır.

Arama stratejisi: İlgili makalelere ulaşabilmek için "impact of ethical leadership, effect of ethical leadership, outcomes of ethical leadership, antecedents of ethical leadership, consequences of ethical leadership, antecedents of knowledge sharing, knowledge sharing" terimleri kullanılmıştır.

Google Scholar, EBSCOhost, Emerald, ScienceDirect, Wiley ve Springer veri tabanlarında ilgili terimler kullanılarak araştırma için gerekli çalışmalara ulaşılmıştır. Herhangi bir süre kısıtlaması kullanılmamış, kronolojik sıralama yapılmamış ve yalnızca İngilizce dilinde yayınlanan çalışmalar dikkate alınmıştır.

Dâhil etme ve hariç tutma ölçütleri: Araştırmaya kanıt sağlayacak çalışmaların belirlenmesi gerekmektedir. Literatürde çok sayıda ve çeşitlilikte çalışmanın yapılmış olması birtakım kıstasların belirlenmesini zorunlu kılmaktadır. Bu doğrultuda, dâhil etme ve hariç tutmaya yönelik birtakım kriterler belirlenmiştir. Bu kriterlerden bazıları aşağıdaki gibidir:

- Yönetim ve insan kaynakları alanında yapılmış, özel sektör çalışanlarına odaklanan araştırma, derleme ve meta analizi makaleler incelemeye dâhil edilecektir.

- Etik liderliğin öncüllerini konu alan çalışmalar ve etik liderliğin bireysel ve örgütsel düzeyde etkilerini konu alan çalışmalar incelenecektir.

- Bilgi paylaşımının öncüllerini konu alan çalışmalar dikkate alınacaktır.

- Etik liderlik ile bilgi paylaşımı arasındaki ilişkiyi konu alan çalışmalar araştırmaya dâhil edilecektir.

- Bilgi paylaşımını, çalışanların karşılıklı bilgi, tavsiye ve uzmanlık alışverişinde bulunması olarak ele alan çalışmalar dikkate alınacaktır.

- Yetersiz örneklem ve analize sahip çalışmalar araştırmadan çıkartılacaktır.

- Tam metnine ulaşılamayan çalışmalar araştırmadan çıkartılacaktır.

- Kitap bölümü, kitap kritiği, editöre mektup, vaka analizi, tez vb. çalışmalar araştırmadan çıkartılacaktır.

Kitchenham (2004) sistematik bir incelemeye dâhil edilecek çalışmaların kalitesini analiz etmek büyük önem taşıdığını ifade etmektedir. Ayrıca, çalışmanın kalitesini ölçmeye yönelik genel kabul gören kesin kriterlerin olmaması, çalışmaların kalitesini değerlendirmeyi çok zorlaştırdığını belirtmektedir. 
Çalışmaların seçimi ve verilerin çıkartılması: Veri tabanlarında ilgili terimlerin taranması sonucunda 2.000 'in üzerinde makaleye ulaşılmıştır. İlk olarak, belirlenen seçim kriterleri uygulanmıştır, başlıklar ve özetler incelenerek gerekli kıstasları taşımayan makaleler araştırmadan çıkartılmıştır. Sonrasında ise birbirini tekrar eden çalışmalar araştırmadan çıkartılmıştır. Toplamda tam metin incelemesi için 107 makaleye ulaşılmıştır. Elde edilen makalelerin detaylı okuması yapıldıktan sonra ilgisiz olduğu düşünülen 56 makale daha araştırmadan çıkartılmıştır. Araştırma örneklemi 51 makaleden oluşmaktadır. Ayrıca, kavramsal literatürü güçlendirmek için ilave 63 makaleden daha yararlanılmıştır.

Veri analizi/sentezi: Makalelerin analiz ve sentezi noktasında veriler üç kategoride incelenmiştir. İlk kategoride etik liderlin tanımı ve önemi, etik liderliğin öncülleri ve etkileri, etik liderliğin örgütsel açıdan değerlendirilmesi yer almaktadır. İkinci kategoride, bilgi paylaşımın tanımı ve önemi, bilgi paylaşımını etkileyen faktörler yer almaktadır. Üçüncü kategoride ise etik liderlik ile bilgi paylaşımı arasındaki ilişki yer almaktadır.

\section{ETIKK LIDERLIK}

\subsection{Etik Liderliğin Tanımı ve Önemi}

Liderlik, ortak hedeflere ulaşmak için bir grup bireyi etkileme süreci olarak tanımlanır. Lider, işletmenin amaç ve hedeflerine ulaşması noktasında çalışanları etkiler ve yönlendirir. Liderler, örgütsel amaçların gerçekleştirilmesi için çalışanları etkilemesi ve yönlendirilmesi sürecinde birçok eylemde bulunma ve karar verme durumunda kalırlar. Liderler verdikleri karar ve eylemlerle çalışanları, örgütü, müşterileri ve diğer paydaşları etkilerler. $\mathrm{Bu}$ süreçte, tüm kararların ve eylemlerin etik değerlere uygun olması işletmenin başarıya ulaşması noktasında önemlidir. $\mathrm{Bu}$ nedenle, birçok araştırmacı, liderliği etik açıdan ele alarak örgüte olan sonuçlarını araştırmışlardır.

Etik olmak konusu "doğru" ve "iyi”"nin farkına varıp buna uygun şekilde davranmanın yanı sıra başkalarının iyiliğini düşünmek, davranışlarının sonucunu hesaplayarak hareket etmek ve adaletli olmayı da gerektirmektedir. Bu bağlamda, liderler, etik davranışlar sergileyerek bu hususta çalışanlar için önemli bir kaynak olmalı ve bunun yanında örgütün ahlaki açıdan gelişiminden de sorumlu olmalıdır (Mihelic vd., 2010: 31). Etik liderliğin iki temel özelliği vardır; ahlaklı bir kişilik ve ahlaklı bir yöneticilik. Ahlaklı kişilik, özellikler açısından doğruluk, dürüstlük ve güvenirlik; davranışsal açıdan, doğru şeyi yapma, açık olmak, kişisel ahlaka dikkat etme; karar verme açısından, değerleri dikkate alma, objektif ve adil olma, toplumu düşünme, etik kararlara uyum gibi birçok özelliği taşımalıdır. Etik yöneticilik ise davranışsal olarak rol model olma, ödüllendirme ve disipline önem verme, etik ve değerler hakkında bilgilendirme gibi özellikleri taşımalıdır (Trevino ve Brown, 2004: 76; Trevino vd., 2000: 136-137). Etik bir lider, mükemmel karar verici olan, görevlerini samimiyetle yerine getiren, kararlarını etkin bir şekilde alan ve karamsar olmayan kişilik özelliklerine sahip bir yöneticidir (Brown ve Trevino, 2006: 602). Ayrıca, Northouse (2007) etik liderin, başkalarına saygı gösteren, başkalarına hizmet eden, tutum ve davranışları ile dürüstlük sergileyen, örgütte adil ve eşit davranan kişilik özelliklerine de sahip olduğunu belirtmiştir.

Trevino vd. (2000) etik liderliğe yönelik kişilik ve yöneticilik bağlamında bir matris önermiştir. $\mathrm{Bu}$ matriste, etik olmayan lider (zayıf ahlaki kişi, zayıf ahlaki yönetici), ikiyüzlü liderlik (zayıf ahlaki kişi, güçlü ahlaki yönetici), etik lider (güçlü ahlaki kişi, güçlü ahlaki yönetici) ve etik olarak "sessiz" veya "tarafsız" liderlik (zayıf / güçlü ahlaki kişi, zayıf ahlaki yönetici). Bu 
doğrultuda, liderler çalışanları için örnek oluşturacak ahlaki standartları ve etik kriterleri oluşturmalı ve etik konusunda çalışanları bilgilendirmelidir. Bunun sonucunda, liderin söyledikleri ve yaptıkları arasında bir tutarlılık söz konusu olur ve böylelikle çalışanlara güven aş1layabilir (Bello, 2012: 229).

Literatürde etik liderlik kavramı, felsefe ve sosyal bilimler açılardan iki farklı perspektifte ele alınmıştır. Etik liderliği, belirlenen standart değerler çerçevesinde ele alan felsefeciler, liderin nasıl olması gerektiğini ortaya koymaya çalışmışlardır. Sosyal bilimler alanında ise etik liderliği oluşturan faktörler ve etik liderlik davranışının sonucunda oluşan etkileri ele alınmıştır (Brown ve Trevino, 2006: 596). Freeman ve Stewart (2006) etik lideri, çalışanlar için örnek oluşturan "doğru değerlere" ve "güçlü karaktere" sahip kişi olarak tanımlar. Brown vd. (2005) ise etik liderliği "kişisel eylemler ve kişiler arası ilişkiler yoluyla normatif olarak uygun davranışın gösterilmesi ve bu tür davranışların iki yönlü iletişim, güçlendirme ve karar verme yoluyla takipçilerin teşvik edilmesi" olarak tanımlamıştır. Ayrıca, Piccolo vd. (2010) etik liderliği, çalışanların olumlu davranışlar sergilemesi noktasında onlara rol model olan, örgütsel bağlılığını arttıran, örgütsel adaleti tesis eden, çalışanların motivasyon ve performansının artmasını sağlayan ve ortak değerleri vurgulayan liderlik biçimi olarak tanımlamaktadır.

Johnson (2005), etik liderliğin dört bileşen çerçevesinde açıklamıştır. Bunlar; amaç, bilgi, otorite ve güvendir. Amaç bileşeni, etik liderin örgütsel amaçlara ulaşmak için kararlı ve tutarlı olması gerekliliğidir. Etik liderliğin bilgi bileşeni, işletmenin yakın ve uzak çevresine ait bilgiyi araştırmasını ve yargılamasını kapsamaktadır. Otorite, etik liderin, karar verme ve buna göre hareket etme gücünü açıklamaktadır. Güven ise, diğer tüm bileşenleri birbirine bağlayan en önemli bileşendir. Etik lider, örgüt içinde ve dışındaki paydaşlara karşı güven tesis eder. Güvenilir yönetici otoritesini kullanmaktan korkmaz, örgütsel amaçlara ulaşmak için çaba sarf eder ve gerekli bilgileri toplar ve kullanır.

\subsection{Etik Liderliğin Öncülleri ve Etkileri}

Literatürde etik liderlik öncülleri ve etkileri açısından birçok değişkenle birlikte incelenmiştir. Etik liderliğin öncülleri olarak kültürel etkiler (Resick vd., 2011), bireysel etik tutumlar (Rahaman vd., 2019), rol modelleme (Brown ve Trevino, 2014), sosyal sorumluluk anlayışı (De Hoogh ve Den Hartog, 2008), liderin bilişsel ahlaki gelişimi (Jordan vd., 2013), güçlendirici liderlik (Hassan vd., 2013), kişilik özellikleri (Brown ve Trevino, 2006; Walumbwa ve Schaubroeck, 2009), temel iş özellikleri (Piccolo vd., 2010) unsurlarının etik liderlik davranışına olan etkileri araştırılmıştır. Ayrıca, Sharma vd. (2019) etik liderlin öncüllerini belirlemeye yönelik geliştirdiği modelde, dönüşümcü, ruhani ve otantik liderliğin, değerler ve idealler, dürüstlük ve doğruluk, insan odaklılık ve sorumluluk, karar verme ve iletişim gibi faktörlerin etik liderliğin oluşumunda etkili olduğunu ortaya koymaktadır.

Etik liderliğin, çalışanların iş ortamındaki davranışlarına olumlu etkisini konu alan birçok araştırma bulunmaktadır. Bunlardan bazıları; lider-üye etkileşimi (Qian vd., 2017), çalışan performansı (Bello, 2012; Walumbwa vd., 2011), çalışan sesliliği davranışı (Walumbwa ve Schaubroeck, 2009), bilgi paylaşımı (Le ve Lei, 2018), çalışanların başarı potansiyeli (Dust vd., 2018), içsel motivasyon (Shafique vd., 2019), yenilikçi davranış (Özsungur, 2019), yaratıcı performans (Ahmad vd., 2019), yaratıcılık (Javed vd., 2018) ekstra rol performansı (Tu ve Lu, 2016) duygusal bağlılık, iş tatmini (Neubert vd., 2009), psikolojik güçlendirme (Javed vd., 2017) işe bağlılık (Engelbrecht vd., 2014), yardımcı olma davranışı, inisiyatif kullanma 
(Kalshoven vd., 2013), öz yeterlilik, etik davranışlar (Bedi vd., 2016), görev önemi, özerklik (Piccolo vd., 2010), iş stresi (Zhou vd., 2015), üretkenlik karşıtı iş davranışları (Bouzari vd., 2020), işten ayrılma niyeti (Elçi vd., 2012) ve bilgi saklamadır (Men vd., 2018).

Brown ve Trevino (2006) uyumlu, dürüst ve vicdanlı kişilik özelliklerinin etik liderliğin önemli öncüleri olduğunu belirtmiştir. Bununla birlikte, kararsız, kaygılı, saldırgan ve makyavelist kişilik özellikleri ise etik liderliği olumsuz yönde etkilediğini ortaya koymaktadır. Ayrıca, Brown ve Mitchell (2010) kişilerin rol model olma özelliğinin de etik liderliğin öncüsü olduğunu ifade etmiştir. Bununla birlikte, Brown ve Trevino (2014) bir kişinin kariyeri boyunca etik bir rol modele sahip olması durumunda, etik liderlik eğilimi göstereceğini savunmuştur. Etik liderler, sergilediği tutum ve davranışlar ile çalışanlara etik ve değerlere yönelik mesajlar iletirler. Kasıtlı ve davranışsal olarak gerçekleştirilen bu yaklaşım, çalışanların dikkatini çeker ve etik davranışlarına model oluştururlar. Bu noktada, etik liderler çalışanların etik ve etik olmayan davranışlarını etkilemeye yönelik proaktif çabalar sarf eder (Trevino vd., 2000: 133134; Trevino vd., 2003: 28). Wright ve Quick (2011) ise liderin sahip olduğu karakterin etik liderliğin önemli belirleyicisi olduğunu savunmaktadır. Etik bir liderin karakteri, çalışanları ve toplumu önemseyen, kişisel ve mesleki hayatında etik, adil ve ilkeli karar veren nitelikte olması gerekmektedir (Brown ve Trevino, 2006: 597). Elçi vd. (2013) cinsiyet farklılığının da etik liderlik davranışı üzerinde etkilerinin olduğunu belirtmektedir. Ayrıca, Trevino ve Brown (2004) liderin içinde bulunduğu koşulların, liderin etik davranışlar sergileme noktasında önemli bir belirleyici olduğunu savunmaktadır. De Hoogh ve Den Hartog (2008) liderlerin sosyal sorumluluk algısının etik liderlik davranışını olumlu yönde etkilediğini belirtmiştir. Liderin sosyal sorumluluk anlayışının göstergeleri; ahlaki-yasal davranış anlayışı, vicdani yükümlülük, başkaları için endişelenme, hareketlerin sonuçları hakkında endişelenme ve kişinin kendi kendini yargılamasıdır. Eisenbeiss (2012) din olgusu bakımından etik liderliğin açıklanmasında dört temel normatif ilkesinin olduğunu belirtmiştir. Bunlar; insancıl yönelim, adalet yönelimi, sorumluluk ve sürdürülebilirlik yönelimi ve ılımlı olma yönelimidir. Ayrıca, sosyal bilimler alanında etik liderlik üzerine yapılan araştırmalarda daha çok insancıl ve adalet yönelimlerine odaklanıldığını ve diğer iki yönelimin ihmal edildiğini savunmaktadır.

Sosyal öğrenme teorisi, çalışanların lideri etik bir lider olarak algılamaları noktasında, liderlerin bireysel özelliklerini ve durumsal etkilerini açıklamaya çalışır. Bu bağlamda, sosyal öğrenme teorisi etik liderliğin öncüllerini ve sonuçlarını açıklamak için önemli bir yaklaşımdır. Sosyal öğrenme teorisi açısından bakıldığında, lider etik davranışlarıyla ilgi çekici ve güvenilir bir rol model olarak çalışanların benzer davranışlar sergilemesi noktasında ilham kaynağı olur. Böylelikle, çalışanlar kendilerinden hangi davranışların beklenildiğini, hangi davranışların da ödüllendirildiğini ve cezalandırıldığını öğrenebilirler (Brown vd., 2005: 119). Sosyal öğrenme yaklaşımının yanı sıra, sosyal değişim teorisi de etik liderlik davranışının açıklanmasında teorik temel olarak kullanılmıştır (Mayer vd., 2009: 3). Cropanzano ve Mitchell (2005) etik liderliği sosyal değişim teori çerçevesinde karşılıklılık ilkesi açısından ele alırken, Mayer vd. (2009) ise çalışanların olumlu davranışlar sergileyerek karşılık vermesinin liderin adil ve dürüst davranışlar sergilemesine bağlı olduğuna değinmektedir.

Resick vd. (2006) karakterin ve dürüstlüğün, bir liderin inançlarına, kararlarına ve eylemlerine rehberlik eden kişisel özelliklerin temelini oluşturduğunu belirtmektedir. Bass ve Avolio (1993), bir liderin dürüst olarak güven vermesi, çalışanların liderin vizyonunu kabul etmeleri açısından kritik öneme sahip olduğunu ortaya koymaktadır. Buradan hareketle, Brown vd. (2005), liderin dürüst tutum ve davranışlar sergileyerek çalışanlara güven vermesi, etik liderin 
taşıması gereken önemli bir kişilik özellik olarak değerlendirmektedir. Kanungo ve Mendonca (1996), fedakârlığın liderliğin etik temelini oluşturduğunu ileri sürmektedir. Herhangi bir ödül beklemeden veya kişilerin refahına saygı göstererek başkalarına yardım etmeyi amaçlayan fedakârlık davranışı da etik liderliğin önemli bir kişilik özelliğidir (Resick vd., 2006: 347). Ayrıca, Trevino vd. (2003) etik liderlerin etik farkındalığa sahip olması gerektiğinden bahsetmekte ve etik farkındalığı da dört başlıkta ele almaktadır; çalışanların ortak iyiliği, araçların ve amaçların etkisi, kısa ve uzun vadeli bakış açısı ve diğer paydaşların bakış açısı ve çıkarlarıdır.

Rahaman vd. (2019) etik liderlik yaklaşımına planlı davranış teorisi açısından ele alarak açıklamıştır. Planlı davranış teorisi, bireylerin davranışlarının, davranışsal niyetlerine göre yönlendirildiğini ileri sürmektedir. Gerçek davranıştan önce gelen bu davranışsal niyet, "insanların davranışı gerçekleştirmek için ne kadar çaba göstermeyi planladıklarını, ne kadar denemeye istekli olduklarını" gösterir. Fishbein ve Ajzen (2010) planlı davranış teorisine göre, tutum olarak davranışsal inançların, bireyin belirli bir davranışı gerçekleştirme ya da gerçekleştirmemeye ilişkin kararlarını yönlendireceğini belirtmiştir. Planlı davranış teorisine göre, etik davranışlar gerçekleştirmeye yönelik olumlu tutumlara sahip bir lider büyük olasılıkla iş ortamında da etik davranışlar sergileme niyetinde olacaktır. Etik tutumlar, doğru olanı savunmak, çalışanlarına karşı saygılı ve güvenilir olmayı gerektirir. $\mathrm{Bu}$ durum sonuç olarak, liderlerin etik liderlik davranışlarının göstergesini oluşturmaktadır. Diğer bir ifadeyle, planlı davranış teorisinden hareketle, liderlerin etik davranışlar sergileme noktasında olumlu tutumlara sahip olmaları durumunda, liderin etik davranışlar sergilemesi beklenmektedir (Rahaman vd., 2019: 737).

Bununla birlikte, etik davranışlar sergileyen bir lider olmak zordur. Üst yönetimin baskısı, çalışanların ihtiyaçları, kişilikleri, tutum ve davranışları, müşteri talep ve beklentileri, rakiplerin stratejileri gibi birçok faktörden dolayı, liderin iş ortamında normatif standartları koruyarak etik kararlar vermesi ve etik davranışlar sergilemesi ahlaki cesaret isteyen bir durumdur (Tanner vd., 2010: 226).

\subsection{Etik Liderliğin Örgütsel Açıdan Değerlendirilmesi}

Liderlerin etik açıdan hatalı davranış ve karar vermeleri sonucunda, Enron ve Worldcom skandallarında görüldüğü gibi işletmelerin itibar ve maddi kayba uğramasına, hatta yok olmasına neden olmuştur (Rahaman vd., 2019: 735). Aynı şekilde, liderlerin sorumsuz, etik olmayan tutum ve davranışlarla hareket etmesi sonucunda, dünyada birçok örgütsel skandallar da patlak vermiştir. Bu bağlamda, işletmelerin başarısı ve performansı liderin etik tutum, davranış ve kararlarıyla yakından ilişkilidir (Sharma vd., 2019: 712).

Etik olmayan lider, çıkarcı ve bencil olma, çalışanların taleplerine ve endişelerine duyarsız kalma, sahip olduğu gücü kendi menfaati doğrultusunda kullanma eğilimindedir (Özdaşlı ve Derya, 2011: 71). Etik liderler ise, çalışanların kendilerini ifade etme (fikirlerini söyleme) ve endişelerini dile getirme noktasında onlara firsat sunmaktadır. Ayrıca, çalışanlara güvene dayalı özerklik vermekte ve karar verme sürecine katılmalarını sağlamaktadır (Brown vd., 2005: 120; De Hoogh ve Den Hartog, 2008: 298). Resick vd. (2006) güç paylaşımı olarak adlandırılan etik liderin bu özelliğinin, çalışanların işleri üzerinde daha fazla kontrol sağlamasını ve liderlerine daha az bağımlı hale gelmelerini desteklediğini belirtmektedir. Güç paylaşımı etik liderliğin güçlendirici yönünü ifade etmekte ve çalışanların işlerini daha anlamlı hale getirmesini sağlamaktadır. Buradan hareketle De Hoogh ve Den Hartog (2008) ahlak, 
adalet, etik rolü netleştirme ve güç paylaşımı işyerinde etik liderliğin bileşenleri olduğunu ifade etmektedir.

Örgüt içerisinde saygı ve güvene dayalı kaliteli ilişkiler, örgütsel başarının en önemli belirleyicileridir. $\mathrm{Bu}$ bağlamda, etik liderlerin, örgüt içerisinde, çalışanlar arasında ilişki kalitesinin artması adına doğruluk, dürüstlük, adalet, eşitlik ve merhamet gibi temel ilkeleri tesis etmesi gerekmektedir (Bello, 2012: 230). Ayrıca, etik liderler, karar vermede ahlaki değerlere ve adalete odaklanan, örgütsel kararların dış paydaşlar üzerindeki etkisini dikkate alan bir tutum sergilemelidir. İşletmenin genel hedeflerine ulaşması adına, çalışanların iş ortamında olumlu tutum ve davranışlarda bulunmalarını sağlamalıdır (Piccolo vd., 2010: 261). Etik lider, etik değerler çerçevesinde, örgütün amacını, vizyonunu ve değerlerini somutlaştırır. Aynı zamanda, örgütsel hedefleri, çalışanların ve dış paydaşların hedefleriyle uyumlaştırır. Etik lider doğruluk, dürüstlük, adalet ve eşitlik değerleri çerçevesinde oluşturduğu çalışma ortamında, belirsizlik ve stres seviyesini düşürmeye yardımcı olmaktadır. Bu durum, çalışanlar açısından huzurlu bir çalışma ortamının oluşmasına ve verimliliğin artmasına yol açmaktadır. Böylelikle, etik liderlik davranışı örgütsel amaçlara ulaşılması noktasında önemli katkılar sunmaktadır (Bello, 2012: 230).

Çalışanlarını önemseyen, adil, doğruluk ve dürüstlük ilkesini benimsemiş, vicdanlı bir lider olarak nitelendirilen etik lider, sergilediği davranışlarla, çalışanların örgütsel bağlılık ve özdeşleşmenin (Sharma vd., 2019; Walumbwa vd., 2011), algılanan örgütsel desteğin (Tan vd., 2019), örgütsel yeniliğin (Shafique vd., 2019) ve algılanan örgütsel uyumun ve örgütsel vatandaşlık davranışlarının (DeConinck, 2015) artmasına, etik iklim (Neubert vd., 2009), etik kültürün (Schaubroeck vd., 2012) ve güvenin (Zhu vd., 2004) oluşmasına, formal iş tanımlarının ötesinde çaba sarf etmesine (Ahmad vd., 2019), yüksek iş performansı (Madenoğlu vd., 2014: 47) ve yenilikçi iş davranışları (Düger, 2020) sergilemesine yol açmaktadır. Ayrıca, etik lider çalışanların sahip olduğu bilgiyi örgüte katkı sağlamak adına yöneticileri ve diğer çalışanlarla paylaşması için desteklemektedir (Abdullah vd., 2019: 1; Le ve Lei, 2018: 183). Bununla birlikte, liderlerin etik davranışlar sergilemesi çalışanların iş ortamında maruz kaldığı stresin (Zhou vd., 2015: 176), örgütsel sinizm (Qian ve Jian, 2020: 207) ve üretkenlik karşıtı iş davranışlarının (Brown ve Trevino, 2006: 595) ve çalışanların işten ayrılma eğilimlerinin azalmasına yol açmaktadır (Elçi vd., 2012: 289). Sonuç olarak, etik liderlik çalışanların örgüt içerisinde olumlu davranışlar sergilemesini ve çalışanların örgüte ve işe karşı sergilediği olumsuz davranışların azalmasını sağlayan önemli bir faktördür. Bu bağlamda, etik liderliğin çalışanların bilgi paylaşımına olumlu etkisinin olduğu düşünülmektedir. Etik liderliğin bireysel ve örgütsel düzeyde etkilerini konu alan çalışmalar ayrıca Tablo 1'de verilmektedir.

Tablo 1. Etik Liderliği Etkilerini Konu Alan Çalışmalar

\begin{tabular}{|c|c|c|c|c|}
\hline Yazar(lar) & Etik Liderliğin Etkileri & Aracı Faktör(ler) & $\begin{array}{l}\text { Düzenleyici } \\
\text { Faktör(ler) }\end{array}$ & $\begin{array}{c}\text { Örneklem } \\
\text { Sayısı }\end{array}$ \\
\hline Qian vd. (2017) & Lider-üye değişimi & - & $\begin{array}{l}\text { Duygusal zekâ ve } \\
\text { birim iş yapisı }\end{array}$ & 265 \\
\hline $\begin{array}{l}\text { Walumbwa vd. } \\
\text { (2011) }\end{array}$ & Çalışan performansı & $\begin{array}{l}\text { Örgütsel } \\
\text { özdeşleşme, lider- } \\
\text { üye değişimi }\end{array}$ & - & 273 \\
\hline
\end{tabular}




\begin{tabular}{|c|c|c|c|c|}
\hline $\begin{array}{l}\text { Walumbwa ve } \\
\text { Schaubroeck } \\
(2009)\end{array}$ & $\begin{array}{l}\text { Çalışan sesliliği } \\
\text { davranışı }\end{array}$ & Psikolojik güven & - & 222 \\
\hline Dust vd. (2018) & $\begin{array}{l}\text { Çalışanların başarı } \\
\text { potansiyeli }\end{array}$ & $\begin{array}{l}\text { Psikolojik } \\
\text { güçlendirme }\end{array}$ & - & 508 \\
\hline Özsungur (2019) & $\begin{array}{l}\text { Çalışanların yenilikçi } \\
\text { davranışı }\end{array}$ & Psikolojik sermaye & - & 376 \\
\hline Ahmad vd. (2019) & $\begin{array}{l}\text { Yaratıcı performans, } \\
\text { örgütsel vatandaşlık } \\
\text { davranışı }\end{array}$ & $\begin{array}{l}\text { Psikolojik } \\
\text { sözleşmenin yerine } \\
\text { getirilmesi }\end{array}$ & - & 248 \\
\hline Neubert vd. (2009) & $\begin{array}{l}\text { Duygusal bağlılık, iş } \\
\text { tatmini }\end{array}$ & Etik iklim & - & 250 \\
\hline Zhou vd. (2015) & İş stresi & Lider-üye değişimi & - & 203 \\
\hline Bouzari vd. (2020) & $\begin{array}{l}\text { Üretkenlik karşıtı iş } \\
\text { davranışları }\end{array}$ & $\begin{array}{l}\text { Kişi-iş uyumu, kişi- } \\
\text { örgüt uyumu }\end{array}$ & - & 192 \\
\hline Elçi vd. (2012) & İşten ayrılma niyetidir & İşle ilgili stres & - & 1093 \\
\hline Elçi vd. (2013) & $\begin{array}{l}\text { Çalışanların anti-sosyal } \\
\text { davranışları }\end{array}$ & Etik iklim & - & 468 \\
\hline Men vd. (2018) & Bilgi saklama & Psikolojik güven & - & 436 \\
\hline Qian ve Jian (2020) & Örgütsel sinizm & $\begin{array}{l}\text { Lider-üye değişimi, } \\
\text { örgütsel özdeşleşme }\end{array}$ & - & 167 \\
\hline Bedi vd., 2016 & $\begin{array}{l}\text { Öz yeterlilik, etik } \\
\text { davranış }\end{array}$ & - & - & $\begin{array}{l}\text { Meta- } \\
\text { Analizi }\end{array}$ \\
\hline $\begin{array}{l}\text { Engelbrecht vd. } \\
\text { (2014) }\end{array}$ & İşe bağl1lık, güven & - & - & 204 \\
\hline $\begin{array}{l}\text { Kalshoven vd. } \\
\text { (2013) }\end{array}$ & $\begin{array}{l}\text { Yardımcı olma } \\
\text { davranışı, inisiyatif } \\
\text { kullanma }\end{array}$ & $\begin{array}{l}\text { Sorumluluk ve iş } \\
\text { özerkliği }\end{array}$ & - & 147 \\
\hline Tu ve Lu (2016) & Ekstra rol performans 1 & Öz yeterlilik & İçsel motivasyon & 208 \\
\hline Javed vd. (2018) & Yaratıcılık & Güven & - & 205 \\
\hline Javed vd. (2017) & Psikolojik güçlendirme & - & - & 183 \\
\hline Tan vd. (2019) & $\begin{array}{l}\text { Algılanan örgütsel } \\
\text { destek }\end{array}$ & - & - & 294 \\
\hline DeConinck (2015) & $\begin{array}{l}\text { Algılanan örgütsel } \\
\text { uyum, örgütsel } \\
\text { özdeşleşme, örgütsel } \\
\text { vatandaşlık davranış1 }\end{array}$ & - & - & 331 \\
\hline Zhu vd. (2004) & Örgütsel bağl1lık, güven & $\begin{array}{l}\text { Psikolojik } \\
\text { güçlendirme }\end{array}$ & - & Derleme \\
\hline Sharma vd. (2019) & $\begin{array}{l}\text { Örgütsel bağlılık, } \\
\text { örgütsel özdeşleşme }\end{array}$ & - & Güven & Derleme \\
\hline Shafique vd. (2019) & $\begin{array}{l}\text { Bilgi paylaşımı, içsel } \\
\text { motivasyon, psikolojik } \\
\text { güçlendirme }\end{array}$ & - & - & 322 \\
\hline
\end{tabular}




\begin{tabular}{|c|c|c|c|c|}
\hline Ma vd. (2013) & Bilgi paylaşımı & - & - & 309 \\
\hline Bavik vd. (2018) & Bilgi paylaşımı & $\begin{array}{l}\text { Çalışan ahlaki } \\
\text { kimliği, bilgi } \\
\text { paylaşım } \\
\text { motivasyonu }\end{array}$ & - & 337 \\
\hline Le ve Lei (2018) & Bilgi paylaşımı & Lidere güven & - & 355 \\
\hline Masood (2020) & $\begin{array}{l}\text { Bilgi paylaşımı, bilgi } \\
\text { saklama }\end{array}$ & $\begin{array}{l}\text { Örgütsel } \\
\text { vatandaşlık } \\
\text { davranışı }\end{array}$ & Prosedürel adalet & Derleme \\
\hline Bhatti vd. (2020) & Bilgi paylaşımı & $\begin{array}{l}\text { Öznel iyi oluş, } \\
\text { sosyal medya }\end{array}$ & - & 406 \\
\hline Tang vd. (2015) & $\begin{array}{l}\text { Bilgi paylaşımı, bilgi } \\
\text { saklama }\end{array}$ & Psikolojik bağlılık & - & 300 \\
\hline
\end{tabular}

\section{BILLGI PAYLAŞIMI}

\subsection{Bilgi Paylaşımının Tanımı ve Önemi}

Bireyin zihninde bilişsel bir olgu olarak kabul edilen 'bilgi', literatürde çeşitli açılardan ele alınmıştır. Lam (2000), bireysel anlamda bilgiyi "bir organizasyona ait bilginin bireyin beyninde ve bedensel becerilerinde bulunan bölümü” olarak tanımlamaktadır. Davenport ve Prusak (1998) ise organizasyon açısından bilgiyi "deneyim, değerler, bağlamsal bilgiler ve uzman görüşlerinin bileşeni” olarak tanımlamaktadır. Ayrıca, Barutçugil (2002) bilgiyi, "bireyin hayatı boyunca deneyimleri ve ögrendiklerinin sonucunda zihninde var olanların toplami" olarak tanımlamaktadir.

Nonaka’ya (1994) göre, bilgi “örtük” ve “açık” bilgi olmak üzere iki kısma ayrılmaktadır. Örtük bilgi, bireyin sahip olduğu bilişsel ve teknik unsurları içermektedir. Bilişsel unsurlar paradigmalar, inançlar ve bakış açılarını içerirken, teknik unsurlar ise somut bilgi birikimi, yetenek ve becerileri kapsamaktadır. Bununla birlikte, örtük bilginin örgüte kazandırılması, bilginin yaratılmasında kilit bir faktör olarak görülmektedir. Açık bilgi ise belirli bir kişiye ait olmamakla birlikte, kaydedilebilen, ulaşılabilen, anlaşılabilen ve gerektiğinde arşivlenebilen bir bilgidir. Bununla birlikte, Lowendahl vd. (2001), bireysel düzeyde organizasyonlarda değer yaratan üç tür bilgiden bahsetmektedir; teknik bilgi (know-how), iş ya da görev bilgisi (knowwhat) ve eğilimsel bilgi (dispositional knowledge). Teknik bilgi, öznel ve zımni olan tecrübeye dayalı bilgiyi içermektedir. İş ya da görev bilgisi, doğası gereği kişiye özgü olan görevle ilgili bilgiyi içermektedir. Eğilimsel bilgi ise doğuştan gelen yetenek, öz-beceri ve kabiliyeti içeren kişisel bilgiyi içermektedir.

Ortak bir hedef doğrultusunda çalışanların sinerjik iş birliğini ifade eden bilgi paylaşımı, van den Hooff ve de Ridder (2004) tarafindan, "bireylerin karşılıklı olarak bilgi alışverişi ve ortaklaşa yeni bilgi oluşturma süreci” olarak tanımlanmaktadır. Ipe (2003) bilgi paylaşımını "bilgiye sahip olan bireyin bilinçli eylemleri çerçevesinde organizasyon içinde başkalarına bilgiyi ulaştırması, bilginin diğer bireyler tarafindan anlaşılabilecek, özümsenebilecek ve kullanılabilecek bir forma dönüş̧ürülme süreci" olarak tanımlamaktadır. Bir diğer tanımda ise Lin (2007) bilgi paylaşımını, "organizasyon içerisinde çalışanların sahip olduğu bilgi, deneyim ve becerilerin karşılıklı değişimini içeren sosyal bir etkileşim kültürü olarak” ifade etmektedir. Çalışanların bilgi gizleme davranışlarının nedenlerinin anlaşılması durumunda, bilgi 
paylaşımının arttırılabileceğini belirten Connelly vd. (2012), bilgi gizleme davranışını “bir kişinin başka bir kişi tarafindan talep edilen bilgiyi saklamaya veya gizlemeye yönelik kasıtlı bir girişimi" olarak tanımlamaktadır.

Goswami ve Agrawal (2018) literatürde yapılan çalışmaların bilgi paylaşımına dört ana konuda odaklandığını belirtmektedir. Bunlar; (1) bilgi paylaşım davranışı odaklı perspektif, (2) bilgi paylaşımının anlaşılması, çerçevesi ve modelleri, (3) bilgi paylaşımında teknoloji odaklı perspektif ve (4) bilgi paylaşımına yönelik engellerdir.

Örgütlerde bilgi paylaşımı, hem resmi (formal) hem de gayri resmi (informal) kanallardan gerçekleşebilir. Resmi bilgi paylaşım kanalları, eğitim programları, planlı çalışma ekipleri ve teknoloji tabanlı iletişim sistemlerini içermektedir. Bu kanallar daha çok "resmi etkileşimler" ya da "amaca yönelik öğrenme kanalları" olarak adlandırılmaktadır. Gayri resmi bilgi paylaşım kanalları ise daha çok öğrenmeyi ve bilgi paylaşımını kolaylaştıran kişisel ilişkileri ve sosyal ağları içermektedir. Bu gayri resmi kanallar ise "ilişkisel öğrenme kanalları" olarak adlandırılmaktadır. Resmi bilgi paylaşım kanalları, çalışanlara bilgiyi paylaşabilecekleri yapılandırılmış bir ortam ve gerekli araçları sağlamaktadır (Bartol ve Srivastava, 2002: 64-65). Böylelikle, çalışanlar tarafından açık ve net bir bilginin paylaşılması ve paylaşılan bilginin hızlı bir şekilde yayılmasına olanak sağlanmaktadır. Bununla birlikte, gayri resmi bilgi paylaşım kanalları çalışanlar arasında iletişimi kolaylaştırmakta ve güveni arttırmaktadır. Bireylerin davranışlarını etkileyen saygı ve arkadaşlığın geliştirmesine yardımcı olmaktadır. Bunun sonucunda, bireyler arasında etkin bir bilgi paylaşımı gerçekleşmektedir (Ipe, 2003: 349).

Bilgi paylaşımı bireysel ve organizasyonel seviyelerde gerçekleşmektedir. Bireysel açıdan bilgi paylaşımı, çalışanların bir işi daha iyi, daha hızlı veya daha verimli yapmalarına yardımcı olmak adına, diğer çalışanlarla etkileşime girmelerini kapsamaktadır. Organizasyon açısından bilgi paylaşımı ise bilgiyi diğer çalışanlar için kullanılabilir hale getirme noktasında, örgüt içinde bulunan deneyime dayalı bilgileri yakalamak, düzenlemek, yeniden kullanmak ve aktarmayı kapsamaktadır (Lin, 2007: 316). Bilgi paylaşım türlerini ve bilginin dönüşümünü açıklamak için Nonaka (1994) bir model önermektedir. Bu model, bilgi paylaşımını açık ve örtük bilgi paylaşımı olmak üzere iki sınıfa ayrılmakta ve arasındaki dönüşümü açıklayabilmek için sosyalleşme, dışsallaştırma, kombinasyon ve içselleştirme kavramlarını ortaya koymaktadır. Ayrıca, bu model dört farklı dönüşümden oluşmaktadır: (1) örtük bilgiden örtük bilgiye, (2) açık bilgiden açık bilgiye, (3) örtük bilgiden açık bilgiye ve (4) açık bilgiden örtük bilgiye. $\mathrm{Bu}$ modelde, bilgi paylaşım süreci örgütsel bilgiyi, içselleştirme ve sosyalleşme süreciyle birlikte, bireysel veya grup bilgisine dönüştürülür. Sonrasında bilgi paylaşımı, bireysel ve grup bilgisini dışsallaştırma ve kombinasyon sürecine dayalı olarak, organizasyonel bilgiye dönüştürülmektedir. Açık bilgi paylaşımı, örgüt içerisinde kurumsallaşmış tüm bilgi paylaşım biçimlerini kapsamakta ve daha yaygın olarak görülmektedir. Bunun nedeni, açık bilgi kolaylıkla yakalanabilir, düzenlenebilir ve aktarılabilir olmasıdır. Buna karşılık, örtük bilgi paylaşımının en etkili yolu yüz yüze etkileşimdir. Örtük bilgi paylaşımında, bireylerin sahip oldukları kapasite, bildiklerini paylaşma ve öğrendiklerini kullanma istekliliği önemli birer etkendir (Wang ve Wang, 2012: 8900).

İşletmelerin belirsizlikten kurtulması ve rekabetçi olabilmesinin yolu, yeni bilgi yaratması ve bilgiyi yönetmesinden geçmektedir. İşletmeler etkin bir şekilde bilgiyi yöneterek; "çalışanların ayrılması sonucunda entelektüel sermaye kayıplarını en aza indirmek, tüm çalışanların gerektiğinde bilgiye kolayca erişmesini sağlayarak iş performansını iyileştirmek, başkalarından bilgi edinme karşılığında ödül sistemini kullanmak ve böylelikle çalışan 
memnuniyetini artırmak, daha iyi ürün ve hizmetler sağlamak ve daha iyi kararlar almaya" çalışmaktadırlar (Yang, 2008: 345). Günümüz şartlarında işletmelerin rekabet üstünlüğü sağlaması, her geçen gün örgütsel öğrenmeye daha fazla bağlı hale gelmektedir. Bu bağlamda, çalışanların yeni bilgileri öğrenmesi, öğrendiği ya da mevcut bilgileri örgüt içerisinde paylaşması, örgütsel öğrenmeyi ve dolayısıyla işletmenin rekabetçi bir konum elde etmesini sağlamaktadır (Gagne, 2009: 571). Bununla birlikte, örgüt içerisinde paylaşılan bilginin doğru, geçerli, eksiksiz olması ve bir değer taşıması gerekmektedir. Paylaşılan bilginin taşıdığı değer, örgütün karar alma mekanizmasını doğrudan etkilemektedir. $\mathrm{Bu}$ doğrultuda, etkin bilgi paylaşımı örgütsel karar alma sürecinin sağlıklı bir şekilde yönetilmesinde önemli bir unsur olarak ortaya çıkmaktadır (Işık, 2018: 642). Ayrıca, Song (2001) işletmede etkili bilgi paylaşımının tesis edilmesi, verimliliğin artırılabilmesini, eğitim maliyetlerinin düşürülebilmesini ve belirsizlikten kaynaklanan risklerin azaltılabilmesini sağlayacağını belirtmektedir.

İşletmelerin varlığını devam ettirebilmesi ve rekabetçi avantaj elde etmesi için yenilikçi olması gerekmektedir. İşletmelerin yenilikçi olabilmesi noktasında ise örtük bilgilerden (beceriler veya deneyimler) yararlanmak ve işletmede var olan açık bilgileri (kurumsallaştırılmış yaklaşımlar veya uygulamalar) kullanmak zorundadır. Diğer bir ifadeyle, örgütlerde bilgi paylaşım uygulamalarının hem açık hem de örtük bilgi paylaşımını içermesi, inovasyonun başarısı için önemlidir. Bu nedenle, bilgi paylaşımını destekleyen bir işletme, yeni fikirler üreterek yeni iş firsatları geliştirebilir ve böylelikle yenilik faaliyetlerinde bulunabilir (Wang ve Wang, 2012: 8900). Ayrıca, Lin (2007b) ve Lin (2007) bilgi paylaşımının bir organizasyonda öğrenme faaliyetlerinin ayrılmaz bir parçası olduğunu ve yenilik faaliyetlerinde de iyileştirmelere yol açtığını belirtmektedir.

\subsection{Bilgi Paylaşımını Etkileyen Faktörler}

Literatürde bilgi paylaşımını etkileyen faktörler genel olarak bireysel ve örgütsel düzeyde ele alınmaktadır. Bilgi paylaşımının öncüllerinden bazıları; örgütsel bağlılık (Chiang vd., 2011), örgütsel vatandaşlık davranışı (Lin, 2008), örgütsel iklim, lidere olan güven (Jain vd., 2015), ödüllendirme, örgüt yapısı (Al-Alawi vd., 2007), algılanan örgütsel destek (Yang vd., 2020), örgütsel özdeşleşme (Subba, 2019), örgüt kültürü, yönetim desteği (Wang ve Noe, 2010), örgütsel iklim (Bock vd., 2005), dönüşümcü liderlik (Han vd., 2016), otantik liderlik (Zeb vd., 2019), güçlendirici liderlik (Srivastava vd., 2006), işlemsel liderlik (Masa'deh vd., 2016), liderüye değişimi (Sharifkhani vd., 2016), iş tatmini, işi benimseme (Teh ve Sun, 2012), bilgi paylaşma niyeti (Amin vd., 2011), karşılıklılık, kişilerarası güven, öz-yeterlik ve algılanan avantajdır (Chen ve Hung, 2010).

Örgütsel vatandaşlık davranışını etkileyen faktörlerin bilgi paylaşımı davranışını da etkileyeceğini vurgulayan Gagne (2009), bu bağlamda, bilgi paylaşımını etkileyen üç temel faktörün olduğunu belirtmektedir. Bunlar; bireysel faktörler (güven, güç kaybı korkusu, sosyal ağlar, kişilik özellikleri, bilgi paylaşma motivasyonu vb.), organizasyonel faktörler (liderlik yaklaşımları, yönetim eksikliği, ödül sistemi, paylaşım firsatları vb.) ve teknolojik faktörler (bilgi teknolojisi ve alt yap1, bilgi teknoloji sistemleri ile ilgili eğitimler vb.). Wang ve Noe (2010) ise bilgi paylaşımına etki eden faktörleri altı başlık altında toplamıştır. Bunlar; 1) örgütsel bağlam (örgüt yapısı, örgüt kültürü, yönetim desteği, ödüller ve teşvikler), 2) kişiler ve ekip özellikleri (ekip özellikleri ve süreçleri, çalışan çeşitliliği, cinsiyet, medeni durum, eğitim ve sosyal ağlar), 3) kültürel özellikler (kültürel boyutlar, ulusal kültür ve diller), 4) 630 
bireysel özellikler (bireysel kişilik özellikleri, iş deneyimi ve uzmanlıklar), 5) motivasyon faktörleri (kişilerarası güven ve adalet, bireysel tutumlar, algılanan fayda ve maliyetler), 6) bilgi paylaşımına ilişkin algılar. Bununla birlikte, Ipe (2003) bilgi paylaşımını etkileyen faktörleri içsel ve dışsal faktörler olmak üzere iki gruba ayırmaktadır. İçsel faktörler, bilgiye bağlı algılanan güç ve paylaşımdan kaynaklanan karşılıklılığı içermektedir. Dışsal faktörler ise kişiler arasındaki ilişki ve paylaşıma yönelik ödülleri içermektedir. Ayrıca, Ipe (2003) bilgi paylaşımına yönelik firsatların varlığı da bilgi paylaşımını etkileyen faktörler arasında yer aldığını belirtmektedir. Ipe'e (2003) göre örgüt bağlamında bilgi paylaşımını etkileyen faktörler Şekil 1'de verilmektedir.

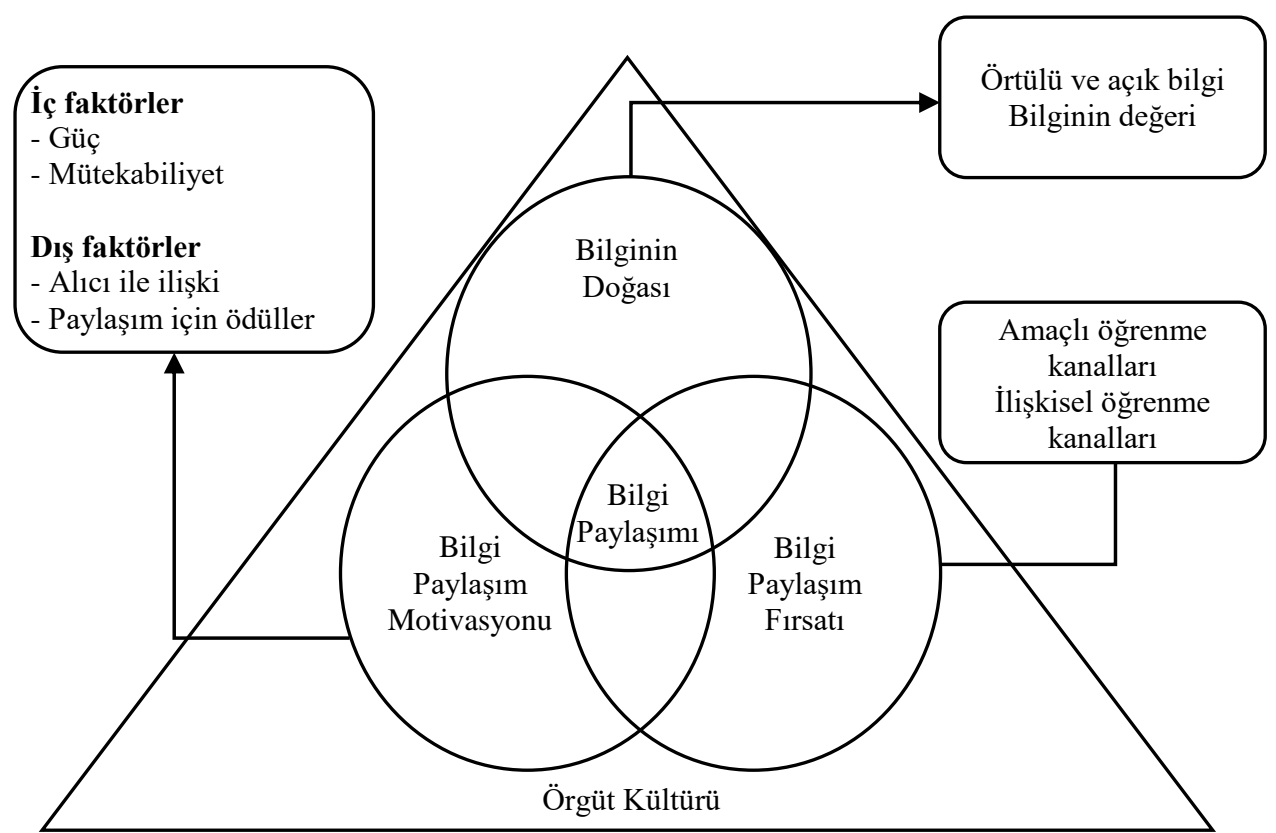

Şekil 1. Örgütlerde Bireyler Arası Bilgi Paylaşımını Etkileyen Faktörler

Kaynak: Ipe, 2003: 352.

Çalışanların sahip olduğu kişisel bilgileri, örgüt ile paylaşmaları noktasında iradeleri dışında zorlanması fayda getirmeyecektir. Aksine, çalışanların bilgi paylaşım davranışlarını kurumsallaştırmak adına, teşvik edici faaliyetlerde bulunulması gerekmektedir. Bu bağlamda, birçok araştırmacı çalışanların bilgi paylaşımını destekleyen faktörleri ortaya çıkarmak için çeşitli araştırmalar yapmıştır. Srivastava vd. (2006) yaptığı çalışmada, bilgi paylaşımı noktasında güçlendirici liderlik yaklaşımının önemli etkisinin olduğunu ortaya koymaktadır. Connelly ve Kelloway (2003) yürüttüğü çalışmada, olumlu sosyal etkileşim kültürü ve yönetim desteğinin bilgi paylaşımını olumlu yönde etkilediğini ve kadınların erkeklere göre bilgi paylaşımında daha hassas davrandıklarını belirtmektedir. Bock vd. (2005) çalışmasında sunduğu modelde, adalet, yenilikçilik ve bağlılık ile karakterize edilen örgütsel iklimin, bireylerin bilgi paylaşımına yönelik tutumlarının ve bireyin sahip olduğu değer yargısı ve inançlarının bilgi paylaşımını etkilediğini ortaya koymaktadır. Park vd. (2004) çalışanları destekleyen, ekip çalışmasını ve özerkliği teşvik eden bir örgüt kültürünün, çalışanlar arasında 
bilgi paylaşımını teşvik ettiğini, çalışanları zorlayan kural odaklı bir örgüt kültürünün ise çalışanların bilgi paylaşımını olumsuz yönde etkilediğini belirtmektedir. Ayrıca, çalışanların sahip olduğu prososyal tutumlar ve bilgiye sahip olma anlayışı somut bilgi paylaşma olasılığını arttırırken, iş ortamındaki arkadaşlık ve kişisel ilişkiler de soyut bilgi paylaşma olasılıklarını arttırmaktadır (Connelly ve Kelloway, 2003: 296). Gagne (2009) önerdiği modelde iş tasarımı, ücretlendirme sistemleri, yönetim tarzları, eğitim ve geliştirme gibi psikolojik ihtiyaçların tatminini etkileyen insan kaynakları uygulamaları, bilgi paylaşımı motivasyonunu etkilediğini belirtmektedir. Ayrıca, içsel olarak motive olmuş çalışanların talep edilmediğinde bile, çalışmaları hakkında konuşma eğiliminde olacağından, bilgi paylaşma davranışları sergileyeceğini ileri sürmektedir. Buna karşın, ödüllendirme gibi dışsal motivasyon araçlarının bilgi paylaşımını içsel motivasyona göre daha az etkilemekte (Andreeva ve Sergeeva, 2016: 167), içsel motivasyon ile bilgi paylaşımı arasındaki ilişkiyi zayıflatmakta (Zhao vd. 2016: 89), hatta dışsal motivasyon aracı olarak ödüllendirmenin, insanların bilgi paylaşımına yönelik tutumlarını olumsuz yönde etkilemektedir (Bock vd., 2005: 88).

Bavik vd. (2018) sosyal sermaye çerçevesinde, bilgi paylaşımını etkilen faktörlerin üç kategoriden oluştuğunu belirtmektedir; ilişkisel, yapısal ve bilişsel faktörler. İlişkisel faktörler, sosyal ilişki türü ve gücü, kişiler arasında karşılıklı güven ve algılanan yönetim desteğini kapsamaktadır. Yapısal faktörler, örgütlerin yapısal çeşitlilik düzeyi, sosyal ağ türleri, örgütsel iletişim sistemi, teşvik sistemi ve bilgi yönetim sistemini kapsamaktadır. Bilişsel faktörler ise bireylerin karşılıklılık normları, örgütsel kültür ve performans hedeflerini kapsamaktadır. Ayrıca, Gagne (2009) bilgi paylaşımını sosyal değişim teorisi (Social Exchange Theory) açısından incelediğinde; örgüt içerisinde etkin bir ödüllendirme sisteminin, çalışanların bilgi paylaşma davranışını olumlu yönde etkileyeceğini belirtmekte ve beceriye dayalı rekabetçi bir ödüllendirme sisteminin geliştirilmesinin, bilgi paylaşımını destekleyici nitelikte olacağını ileri sürmektedir. Bununla birlikte, somut ödüllendirmenin bilgi paylaşma motivasyonu açısından çoğu zaman yetersiz olduğunu, fakat örgüt içerisinde tanınmanın somut ödüllendirmelerden daha fazla çalışanları bilgi paylaşımına teşvik edeceğini belirtmektedir. Bir diğer teori olan mantıklı eylem teorisine (Theory of Reasoned Action) göre, kişinin bir davranışta bulunma niyeti, o davranışa yönelik tutumlar ve sosyal normların algılanmasıyla belirlenmektedir. Tutumlar, davranışın sonuçlarına ilişkin inançlara göre oluşmaktadır. Bireylerin bilgiyi paylaşmaya yönelik niyetinin oluşması için, önce paylaşmaya yönelik tutumları ve paylaşım normlarına ilişkin algıları etkileyen faktörlerin belirlenmesi gerekmektedir (Cabrera ve Cabrera, 2005: 721).

Çalışanların sergilediği tutum ve sahip olduğu yetkinlikler bazen bilginin paylaşılması noktasında engel teşkil edebilir. Çalışanların bilgiyi paylaşmanın ve aktarmanın önemini idrak edememesi, kişisel güvensizlikten dolayı cahil olarak görülme korkusu, iş geliştirme için uygun olmama korkusu tutumsal olarak bilgi paylaşma isteksizliğine yol açabilmektedir. Aynı şekilde, çalışanların "bilgi güçtür" anlayışına sahip olması ve bilgi paylaşımı sonrasında üstünlüğünü kaybedeceğinden korkması da bilgi paylaşma isteksizliğini arttırabilmektedir (Yang, 2008: 347). Ayrıca, çalışanlar örgüt içerisinde hiyerarşi ya da güç dengesizliği hissettiğinde, bilgi paylaşma eğiliminde bulunmamaktadırlar (Connelly ve Kelloway, 2003: 295). Bilgi paylaşımının öncüllerini bireysel ve örgütsel düzeyde ele alan çalışmalar Tablo 2'de verilmektedir.

Tablo 2. Bilgi Paylaşımının Öncüllerini Konu Alan Çalışmalar 


\begin{tabular}{|c|c|c|c|c|}
\hline Yazar(lar) & Bilgi Paylaşımının Öncülleri & $\begin{array}{c}\text { Aracı } \\
\text { Faktör(ler) }\end{array}$ & $\begin{array}{l}\text { Düzenleyici } \\
\text { Faktör(ler) }\end{array}$ & $\begin{array}{c}\text { Örneklem } \\
\text { Sayısı }\end{array}$ \\
\hline Gagne vd. (2019) & Bilgi paylaşma motivasyonu & - & - & 394 \\
\hline $\begin{array}{l}\text { Andreeva ve } \\
\text { Sergeeva (2016) }\end{array}$ & İçsel ve dışsal motivasyon & - & - & 329 \\
\hline $\begin{array}{l}\text { Srivastava vd. } \\
(2006)\end{array}$ & Güçlendirici liderlik & - & - & 389 \\
\hline Bock vd. (2005) & $\begin{array}{l}\text { Örgütsel iklim, bireyin değer yargısı ve } \\
\text { inançlar, bilgi paylaşımına yönelik } \\
\text { tutumlar }\end{array}$ & - & - & 154 \\
\hline $\begin{array}{l}\text { Chiang vd. } \\
\text { (2011) }\end{array}$ & Örgütsel bağl1lık & - & - & 198 \\
\hline Lin (2008) & Örgütsel vatandaşlık davranışı & - & Cinsiyet & 314 \\
\hline $\begin{array}{l}\text { Bartol ve } \\
\text { Srivastava (2002) }\end{array}$ & Ödüllendirme sistemi & & - & Derleme \\
\hline Ipe (2003) & $\begin{array}{l}\text { Bilginin doğası, bilgi paylaşım firsatı, } \\
\text { bilgi paylaşma motivasyonu }\end{array}$ & - & - & Derleme \\
\hline Jain vd. (2015) & Örgütsel iklim, lidere olan güven & - & - & 231 \\
\hline $\begin{array}{l}\text { Al-Alawi vd. } \\
\text { (2007) }\end{array}$ & $\begin{array}{l}\text { Güven, iletişim, bilgi sistemleri, } \\
\text { ödüllendirme, örgüt yapısı }\end{array}$ & - & - & 231 \\
\hline $\begin{array}{l}\text { Chen ve Hung } \\
\text { (2010) }\end{array}$ & $\begin{array}{l}\text { Karşılıklılık, kişilerarası güven, öz- } \\
\text { yeterlik, algılanan avantaj }\end{array}$ & - & - & 323 \\
\hline Han vd. (2016) & Dönüşümcü liderlik & $\begin{array}{c}\text { Örgütsel } \\
\text { vatandaşl1k } \\
\text { davranış1 }\end{array}$ & - & 395 \\
\hline $\begin{array}{l}\text { Teh ve Sun } \\
(2012)\end{array}$ & İş tatmini, işi benimseme & $\begin{array}{l}\text { Örgütsel } \\
\text { vatandaşl1k } \\
\text { davranış1 }\end{array}$ & - & 116 \\
\hline Lin (2007) & $\begin{array}{l}\text { Başkalarına yardım etmekten zevk alma, } \\
\text { öz-yeterlik, üst yönetim desteği }\end{array}$ & - & & 172 \\
\hline $\begin{array}{l}\text { Wang ve Noe } \\
(2010)\end{array}$ & $\begin{array}{l}\text { Örgüt yapısı, örgüt kültürü, yönetim } \\
\text { desteği, ödüller ve teşvikler, ekip } \\
\text { özellikleri ve süreçleri, çalışan çeşitliliği, } \\
\text { cinsiyet, medeni durum, eğitim, sosyal } \\
\text { ağlar, kültürel boyutlar, ulusal kültür ve } \\
\text { diller, kişilik özellikleri, iş deneyimi, } \\
\text { uzmanlıklar, kişilerarası güven ve adalet, } \\
\text { bireysel tutumlar, algıllanan fayda ve } \\
\text { maliyetler, bilgi paylaşımına ilişkin } \\
\text { algılar }\end{array}$ & - & - & Derleme \\
\hline Yang vd. (2020) & Algılanan örgütsel destek & - & Öz-benlik & 145 \\
\hline Zeb vd. (2019) & Otantik liderlik & - & - & 300 \\
\hline $\begin{array}{l}\text { Sharifkhani vd. } \\
\text { (2016) }\end{array}$ & Lider-üye değişimi & - & - & 116 \\
\hline
\end{tabular}




\begin{tabular}{|c|c|c|c|c|}
\hline $\begin{array}{l}\text { Masa'deh vd. } \\
\text { (2016) }\end{array}$ & İşlemsel liderlik & - & - & 179 \\
\hline Amin vd. (2011) & Bilgi paylaşma niyeti & & $\begin{array}{l}\text { İş deneyimi, } \\
\text { cinsiyet, } \\
\text { eğitim }\end{array}$ & 186 \\
\hline Subba (2019) & Örgütsel özdeşleşme & - & - & 246 \\
\hline
\end{tabular}

\section{ETIKK LİDERLİK İLE BİLGI PAYLAŞIMI ARASINDAKİ İLISŞKİ}

Bilgi paylaşımı cömert ve etik bir bağış eylemi olarak kabul edilirken, bilgiyi saklayarak kişinin kendi çıkarını ve pazarlık gücünü arttırmaya çalışması ise istenmeyen bir davranış olmakla birlikte, işletmeye de zarar verebilmektedir. Bu nedenle, Bavik vd. (2018) örgütün gelişimi için gerekli olan bilginin saklanması ahlaki bir ihlal olarak kabul edildiğini belirtmektedir. Örgütsel bağlamda ise, açık veya örtük bilgi paylaşım normlarının ihlal edilmesi, istenmeyen sonuçlara yol açabileceğinden dolayı, kişilerin niyetine bakılmaksızın etik olmayan davranış olarak kabul edilmektedir (Bavik vd., 2018: 323). Bu nedenle, bilgi paylaşımının büyük bir ahlaki öneminin olduğu söylenebilir. Bilgi paylaşımının, çalışanların örgüte olan ahlaki bir sorumluluğu olarak değerlendirilmesi (Lin, 2007a: 411-412), bilgi paylaşım davranışını etik açısından incelenmesi gerekliliğini ortaya koymaktadır. Bununla birlikte, çalışanların bilgi paylaşımını etkileyen en önemli faktörlerden biri olan yönetim anlayışının da etik çerçevede ele alınması gerekmektedir. $\mathrm{Bu}$ bağlamda, etik liderlik davranışı ve çalışanların bilgi paylaşma davranışı yukarıdaki bölümlerde ayrı ayrı ele alınmaktadır. Bu bölümde, etik liderin sergilediği tutum ve davranışların, çalışanların bilgi paylaşma davranışında bulunması noktasındaki etkileri incelenmektedir.

Lider örgüt içerisinde sergilediği tutum ve davranışlar ile çalışanları birçok açıdan etkilemektedir. Liderin olumlu tutum ve davranış sergilemesi, çalışanların da işletmeye katkı sağlaması noktasında ekstra rol davranışı sergilemesine yol açmaktadır. Bunun tam tersi durumda ise çalışan işletmeye katkı sağlamak yerine işletmeye doğrudan ya da dolaylı olarak zarar verebilmektedir. Bu bağlamda, lider sergilediği etik davranışlar ile çalışanlarına güven verirken, aynı zamanda onlara rol model olabilir. $\mathrm{Bu}$ durumda ise çalışanların, liderin davranışlarına karşılıkta bulunması beklenmektedir. İster karşılıklılık ilkesi gereği ister rol model davranışı gereği liderin çalışanlar ile bilgi paylaşımında bulunması, örgüt içerisinde bilgi oluşumunu ve bilgi paylaşımını kolaylaştıracak bir ortamın oluşmasını ve aynı zamanda çalışanların çeşitli bilgileri öğrenmesi ve öğrendiği bilgileri diğer çalışanlarla paylaşmasını sağlayacaktır (Nonaka vd., 2006: 1190; O'Neill ve Adya, 2007: 419). Ayrıca, Connelly ve Kelloway (2003) yönetimin çalışanları desteklemesi, iş ortamında bilgi paylaşım kültürünün oluşmasını sağlayacağını belirtmektedir. Bunu destekler nitelikte, Chiu vd. (2006) yaptıkları çalışmada yöneticilerin ve ortak bir vizyona sahip olmanın, çalışanların bilgi paylaşımı davranışında bulunmasını olumlu yönde etkilediğini ortaya koymaktadır. Srivastava vd. (2006) ise çalışmasında, güçlendirici liderlik davranışının çalışanların bilgi paylaşımında bulunmasında önemli bir etkisinin olduğu sonucuna ulaşmaktadır.

Bilgi paylaşımının ahlaki önemi göz önüne alındığında, etik liderlik davranışının bilgi paylaşımını teşvik edeceği öngörülmektedir. Brown ve Trevino (2006) etik liderliği, bilgi paylaşımını destekleyen adalet, açıklık ve güvenilirlik gibi temel unsurlar çerçevesinde, ahlaki açıdan arzu edilen özelliklerle karakterize etmektedir. Etik liderliğin davranışsal özellikleri açısından bakıldığında; örgüt içerisinde algılanan adalet çalışanların bilgi paylaşımını olumlu 
yönde etkilemektedir. Çalışanlar organizasyonel kararların adil ve hakkaniyetli olduğunu hissettiğinde, yönetime ve örgüte karşı daha yüksek güven duyacaktır. Bu durum ise çalışanların bildiklerini çalışma arkadaşları ve yöneticileri ile paylaşmasını desteklemektir (Cabrera ve Cabrera, 2005: 730). Flood vd. (2001) adalet algısının yanı sıra eşitlik algısının da çalışanların beklentileri karşılaması adına, işgörenlerin örgüte katkıda bulunma yükümlülüğü duygusuna olumlu bir etkisinin olduğunu belirtmektedir. $\mathrm{Bu}$ bağlamda, eşitlik algısının çalışanların bilgi paylaşımına olumlu yönde etkisinin olacağı söylenebilir. Lin (2007b) çalışanların karar verme sürecine katılmalarının bilgi paylaşımı davranışına olumlu etkisinin olduğunu, geniş katılım ile karar vermenin (özerkliği etkileyen) olumlu yönde bilgi paylaşımıyla ilişkili olduğunu, Quigley vd. (2007) ise güvenin ve bireysel öz-yeterliğin bilgi paylaşımı davranışını olumlu yönde etkilediğini belirtmektedir. Hsu vd. (2007) güvenin, çalışanların bilgi paylaşımında önemli bir kaldıraç olduğunu belirtmektedir. Karşılıklı güven ortamında, çalışanlar arasındaki bağlar daha güçlü olmakta, karşılıklı ilişkinin kapsamı genişlemekte ve çalışanlar arasında sorunsuz bir iş birliği sağlanmaktadır. Bu durum, çalışanların bilgilerini diğer çalışanlarla paylaşma noktasında daha fazla istekli olmalarına yol açmaktadır (Hsu vd., 2007: 166). Ayrıca, Piccolo vd. (2010) etik bir liderin şeffaf olduğunu ve çalışanlara görevleri hakkında yapıcı fikirler sağlayarak, bilgi paylaşımını teşvik ettiğini ortaya koymaktadır.

Etik liderler, çalışanların bilgilerini paylaşması noktasında onları motive etmekte ve onlara gerekli firsatı sunmaktadır. Liderler, etik kodlar, etik karar verme süreçleri, adil ödül sistemi ve etkili bir iletişim sayesinde, bilgi paylaşımını kısıtlayan fiziksel engelleri azaltmakta ve çalışanları bilgi paylaşımı noktasında motive etmektedirler. Ayrıca, etik liderler bilgi paylaşımında yapısal engelleri azaltmak için de kişisel olarak güven, dostluk, adalet gibi örgütsel değerleri çalışanlara yansıtmaktadır. Böylelikle, etik liderler iş ortamında güvene dayalı ilişkilerin oluşumunu desteklemekte ve çalışanların bilgi paylaşımında bulunmasını teşvik etmektedirler. Ayrıca, etik liderlerin sahip olduğu ahlaki yöneticilik yönü, çalışanlar arasında bilgi paylaşımı için bir motivasyon kaynağı olmakta ve çalışanlar arasında bilgi paylaşımını olumlu yönde etkilemektedir (Bavik vd., 2018: 324).

Ahlaklı bir kişi olarak etik lider, bireylerin iş ortamındaki istenmeyen davranışlarını değiştirebilmektedir. Zhu vd. (2011), etik liderin çalışanların ahlaki kimliğini ve ahlaki benlik anlayışını dönüştürebileceğini veya şekillendirebileceğini belirtmektedir. Etik liderler sunduğu değer ve sergilediği davranışlar ile rol model olarak, çalışanlara tutum ve davranışlarına referans olmaktadır (Schaubroeck vd., 2012: 1056). Bu bağlamda, Wang (2004) ahlaki açıdan arzu edilen bir davranış olarak, bireylerin bilgi paylaşımını ahlaki bir yükümlülük olarak algılayacağını ve dolayısıyla ahlaki bir kişinin yapması gerektiği gibi bilgi paylaşımında bulunacağını belirtmektedir. Böylelikle, bilgi paylaşımı davranışları sergileyen çalışanlar, muhtemelen bir etik lider tarafından ödüllendirilecektir (Tang vd., 2015: 72).

Organizasyon içinde bilgi paylaşımına yönelik güçlü normların olması, bilgi paylaşımı için yeterli olduğu anlamına gelmez, ayrıca bilgi paylaşımını güven ve iş birliği çerçevesinde teşvik edici olan bir 'şefkat' kültürünün oluşturulması gerekmektedir (Lengnick-Hall ve LengnickHall, 2003: 93). Cabrera ve Cabrera (2005) göre bilgi paylaşımını etkileyen en önemli faktörlerden ikisi; güven ve karşılıklılık beklentisidir. Bu bağlamda, açık ve güvenilir bir örgütsel kültürde, çalışanların bildiklerini paylaşmaya daha istekli olmaları beklenilmektedir. Bu kültürün oluşmasında açık iletişim, eşitlik, karar alma süreçlerinde adalet, algılanan örgütsel destek çok önemlidir (Cabrera ve Cabrera, 2005: 729). Bu noktada, etik liderliğin sergilediği 
tutum ve davranışlar ile 'şefkat' kültürünün ya da açık ve güvenilir bir örgüt kültürünün oluşmasında önemli bir etken olduğu söylenebilir.

\section{SONUÇ VE DEĞERLENDİRME}

Dinamik ve küreselleşen dünya ekonomisinde, bilgi işletmeler tarafindan önemli stratejik bir güç ve rekabet noktasında önemli bir kaynak olarak görülmektedir. Rekabet üstünlüğünün birincil kaynağı olarak görülen bilgi, aynı zamanda işletmelerin uzun dönemde sürdürülebilirliği ve başarısı için kritik bir önem taşımaktadır. Diğer bir ifadeyle, işletmelerin başarılı olması, karlılığını arttırması ve ticari rekabet gücü kazanması giderek daha fazla kurumsal bilgiyi yaratma ve kullanma becerisine dayanmaktadır. Bir kuruluşun bilgiyi etkin bir şekilde kullanma becerisi, bilgiyi oluşturan, paylaşan ve kullanan çalışanlarına büyük ölçüde bağlıdır. Bilgiden yararlanmanın yolu ise çalışanların bilgilerini geliştirmeleri ve sahip oldukları bilgileri paylaşmaları ile mümkün olmaktadır.

Bilgi paylaşımı ile bilginin diğer kişilere aktarılması bilgiyi tüketmez, aksine örgütün bilgiyi etkin bir şekilde kullanma kapasitesini arttırarak, yeni bilgilerin oluşturulmasına olanak sunmaktadır. Le ve Lei (2018) bilginin değerinin artması için paylaşılması gerektiğini vurgulamakta, Göksel ve Aydıntan (2017) ise kullanılmayan bilginin bir değerinin olmadığını belirtmektedir. Bilgi paylaşımı ile bilgi aktarımı birbirlerinden iki farklı kavramdır. Bilgi aktarımı, bilginin bir kişi tarafından paylaşılmasını ve alıcının bilgi edinmesini kapsamaktadır. Bilgi paylaşımı ise bireylerin sahip olduğu göreve yönelik bilgilerini ve bilgi birikimini, kişilerin başkalarına yardım etmesi, yeni fikirler geliştirmesi ve iş birliğini teşvik etmesi için sunduğu bir süreç olarak ifade edilmektedir.

Bilgi paylaşımı, bilgiyi örgüt içerisinde diğerlerine ulaştırma eylemi olarak kabul edilmekte olup, bu davranışın meydana gelmesinde ise birçok etken bulunmaktadır. Bilgi paylaşımı bir örgütte kendiliğinden ortaya çıkmaz, bunun için gerekli faktörlerin var olması ve şartların oluşması gerekmektedir. Bu noktada lider, bilgi paylaşımının oluşumunu etkileyen ve derecesini belirleyen güçlü bir faktör olarak karşımıza çıkmaktadır (Srivastava vd., 2006: 1241). Lider, bilginin önemini yansıtan bir örgüt kültürünün oluşturulmasında, bilginin yaratılması ve paylaşılmasının özendirilmesinde, bilgi yönetim stratejilerinin geliştirilmesinde ve vizyonunun belirlenmesinde kilit rol oynamaktadır (Doğan ve Kılıç, 2009: 107). Bu bağlamda, etkili bir liderlik stili olarak kabul edilen etik liderliğin, çalışanların bilgi paylaşımı davranışı sergilemesinde olumlu etkisinin olduğu kabul edilmektedir. Etik liderliğin güven, adalet, eşitlik, şeffaflık gibi önemli faktörlere dayanan davranışları, çalışanları olumlu bir şekilde etkilemekte ve bunun sonucunda çalışanlar bilgi paylaşımı noktasında olumlu davranışlar sergilemektedirler. Araştırmacılar tarafından yapılan birkaç ampirik çalışma bunu kanıtlamaktadır (Bavik vd., 2017; Bhatti vd., 2020; Le ve Lei, 2018; Masood, 2020; Tang vd., 2015). Etik liderlik ile çalışanların bilgi paylaşımı arasındaki ilişkide, Bavik vd. (2017) çalışanların ahlaki kimliği ve bilgi paylaşım motivasyonu, Le ve Lei (2018) lidere olan güven, Bhatti vd. (2020) öznel iyi oluş ve sosyal medya, Masood (2020) örgütsel vatandaşlık davranış1 ve prosedürel adalet, Tang vd. (2015) ise psikolojik bağlılık değişkenleri ile birlikte ele alınmıştır. Yapılan bu çalışmalarda, etik liderlik ile çalışanların bilgi paylaşımı arasındaki ilişki sınırlı olarak incelendiği görülmektedir. Ayrıca, detaylı literatür taraması sonucuna göre; etik liderliğin bazı çıktılarının aynı zamanda bilgi paylaşımının öncülleri olduğu anlaşılmaktadır. Bu ortak faktörler; lider-üye değişimi, örgütsel vatandaşlık davranışı, iş tatmini, öz-yeterlilik, lidere olan güven, algılanan örgütsel destek, içsel motivasyon, örgütsel bağlılık ve örgütsel özdeşleşmedir. Belirlenen bu ortak faktörler çerçevesinde literatürde yeterince ilişki 636 
kurulmadığı sonucuna ulaşılmıştır. Etik liderlik ile bilgi paylaşımı arasındaki ilişki, sosyal değişim teorisi, rol model teorisi, karşılıklılık teorisi, sosyal öğrenme teorisi vb. teoriler çerçevesinde ele alınmadığı gözlemlenmektedir. Bununla birlikte, kültürel farklılıkların etik liderlik ile bilgi paylaşım davranışı arasındaki ilişkiye olan muhtemel etkileri araştırmacılar tarafından incelenmediği de görülmektedir.

Bilgi paylaşımı davranışının öncülleri çerçevesinde yapılacak olan çalışmalar, gerçek manada etik liderliğin etkisini ortaya koyabilir. Bu bağlamda, çalışanların ve liderin kişilik özellikleri, örgüt kültürü, örgüt iklimi, ücretlendirme ve ödül sistemi, eğitim ve geliştirme faaliyetleri, işyeri arkadaşlığı, örgüt içi iletişim vb. unsurları da kapsayacak olan çalışmaların yapılması araştırmacılara önerilmektedir.

\section{KAYNAKÇA}

ABDULLAH, M. I., DECHUN, H., ALI, M. \& USMAN, M. (2019). "Ethical Leadership and Knowledge Hiding: A Moderated Mediation Model of Relational Social Capital, and Instrumental Thinking”. Frontiers in Psychology, 10(2403): 1-14.

AHMAD, I., DONIA, M. B. L., KHAN, A. \& WARIS, M. (2019). “Do as I say and do as I do? The mediating role of psychological contract fulfillment in the relationship between ethical leadership and employee extra-role performance". Personnel Review, 48(1): 98117.

Al-ALAWI, A. L., Al-MARZOOQI, N.Y. \& MOHAMMED, Y. F. (2007). “Organizational culture and knowledge sharing: critical success factors". Journal of Knowledge Management, 11(2), 22-42.

AMIN, A., HASSAN, M. F., ARIFFIN, M. B. M. \& REHMAN, M. (2011). "Knowledge sharing: two-dimensional motivation perspective and the role of demographic variables”. Journal of Information \& Knowledge Management, 10(2): 135-149.

ANDREEVA, T. \& SERGEEVA, A. (2016). "The more the better ... or is it? The contradictory effects of HR practices on knowledge-sharing motivation and behaviour". Human Resource Management Journal, 26(2): 151-171.

BARTOL, K. M. \& SRIVASTAVA, A. (2002). "Encouraging knowledge sharing: The role of organizational reward systems". Journal of Leadership \& Organizational Studies, 9(1): 64-77.

BARUTÇUGİL, İ. (2002), Bilgi Yönetimi, Kariyer Yayıncılık, İstanbul.

BASS, B. M. \& AVOLIO, B. J. (1993). Transformational Leadership: A Response to Critiques, Chemers \& Ayman (eds.), Leadership Theory and Research Perspectives and Qualitys, Academic Press, San Diego.

BAVIK, Y. L., TANG, P. M., SHAO, R. \& LAM, L. M. (2018). "Ethical leadership and employee knowledge sharing: Exploring dual-mediation paths". The Leadership Quarterly, 29(2): 322-332.

BEDI, A., ALPASLAN, C.M. \& GREEN, S. (2016). “A Meta-analytic review of ethical leadership outcomes and moderators". Journal of Business Ethics, 139(3): 517-536. 
BELLO, S. M. (2012). "Impact of Ethical Leadership on Employee Job Performance". International Journal of Business and Social Science, 3(11): 228-236.

BHATTI, M. H., AKRAM, U., BHATTI, M. H., RASOOL, H. \& SU, X. (2020). “Unraveling the effects of ethical leadership on knowledge sharing: the mediating roles of subjective well-being and social media in the hotel industry". Sustainability, 12(20): 1-20.

BOCK, G. W., ZMUD, R. W., KIM, Y.-G. \& LEE, J. N. (2005). "Behavioral intention formation in knowledge sharing: Examining the roles of extrinsic motivators, socialpsychological forces, and organizational climate”. MIS Quartely, 29: 87-111.

BOUZARI, M., SAFAVI, H.P. \& VATANKHAH, S. (2020). "The impact of ethical leadership on counterproductivity among cabin crews". European Journal of Tourism Research 25(2507): 1-20.

BROWN, M. E. \& MITCHELL, M. S. (2010). "Ethical and Unethical Leadership: Exploring New Avenues for Future Research”. Business Ethics Quarterly, 20(4): 583-616.

BROWN, M. E. \& TREVINO, L. K. (2006). "Ethical leadership: a review and future directions". The Leadership Quarterly, 17(6): 595-616.

BROWN, M. E. \& TREVINO, L. K. (2014). "Do Role Models Matter? An Investigation of Role Modeling as an Antecedent of Perceived Ethical Leadership". Journal of Business Ethics, 122: 587-598.

BROWN, M. E., TREVINO, L. K. \& HARRISON, D. A. (2005). "Ethical Leadership: A Social Learning Perspective for Construct Development and Testing”. Organizational Behavior and Human Decision Processes, 97: 117-134.

CABRERA, E. F. \& CABRERA, A. (2005). "Fostering knowledge sharing through people management practices". International Journal of Human Resource Management, 16(5): 720-735.

CHEN, C. J. \& HUNG, S. W. (2010). “To give or to receive? Factors influencing members' knowledge sharing and community promotion in professional virtual communities". Information \& Management, 47(4): 226-236.

CHIANG, H., HAN, T. \& CHUANG, J. (2011). "The relationship between high-commitment HRM and knowledge-sharing behavior and its mediators". International Journal of Manpower, 32(5/6): 604-622.

CHIU, C. M., HSU, M. H. \& WANG, E. T. G. (2006). "Understanding knowledge sharing in virtual communities: An integration of social capital and social cognitive theories". Decision Support Systems, 42(3): 1872-1888.

CONNELLY, C. E. \& KELLOWAY, E. K. (2003). "Predictors of employees' perceptions of knowledge sharing culture". Leadership and Organization Development Journal, 24(5/6): 294-301.

CONNELLY, C. E., ZWEIG, D., WEBSTER, J. \& TROUGAKOS, J. P. (2012). “Knowledge hiding in organizations". Journal of Organizational Behavior, 33(1): 64-88. 
CROPANZANO, R. \& MITCHELL, M. S. (2005). "Social exchange theory: An interdisciplinary review". Journal of Management, 31: 874-900.

DAVENPORT, T. \& PRUSAK, L. (1998). Working knowledge: How organizations manage what they know, Harvard Business School Press, Boston.

De HOOGH, A. H. B. \& Den HARTOG, D. N. (2008). "Ethical and despotic leadership, relationships with leader's social responsibility, top management team effectiveness and subordinates' optimism: A multi-method study". The Leadership Quarterly, 19(3): 297311.

DECONINCK, J. B. (2015). "Outcomes of ethical leadership among salespeople”. Journal of Business Research, 68(5): 1086-1093.

DOĞAN, S. \& KILIÇ, S. (2009). "Bilgi yönetiminde liderliğin rolü üzerine kavramsal bir inceleme”. Süleyman Demirel Üniversitesi İktisadi ve İdari Bilimler Fakültesi Dergisi, 14: 87-111.

DUST, S. B., RESICK, C. J., MARGOLIS, J. A., MAWRITZ, M. B. \& GREENBAUM, R. L. (2018). "Ethical leadership and employee success: Examining the roles of psychological empowerment and emotional exhaustion”. The Leadership Quarterly, 29(5): 570-583.

DÜGER, Y. S. (2020). "Etik Liderlik ve Çalışanların Yenilikçi Davranışı: Lider-Üye Etkileşimi ve Duygusal Zekânın Düzenleyici Aracılık Modeli”. Ahi Evran Üniversitesi Sosyal Bilimler Enstitüsü Dergisi, 6(3): 706-725.

EISENBEISS, S. A. (2012). "Re-thinking ethical leadership: An interdisciplinary integrative approach”. Leadership Quarterly, 23(5): 791-808.

ELÇİ, M., ŞENER, İ. \& ALPKAN, L. (2013). "The impacts of ethical leadership on the antisocial behavior of employees: the mediating role of ethical climate". Journal of Global Strategic Management, 14: 57-66.

ELÇİ, M., ŞENER, İ., AKSOY, S. \& ALPKAN, L. (2012). “The impact of ethical leadership and leadership effectiveness on employees' turnover intention: The mediating role of work related stress”. Procedia Social \& Behavioral Sciences, 58: 289-297.

ENGELBRECHT, A.S, HEINE, G. \& MAHEMBE, B. (2014). "The influence of ethical leadership on trust and work engagement: An exploratory study". SA Journal of Industrial Psychology/SA Tydskrif vir Bedryfsielkunde, 40(1): 1-9.

FISHBEIN, M. \& AJZEN, I. (2010). Predicting and Changing Behavior: The Reasoned Action Approach, Psychology Press, Taylor and Francis, New York.

FLOOD, P. C., TURNER, T., RAMAMOORTHY, N. \& PEARSON, J. (2001). "Causes and Consequences of Psychological Contracts among Knowledge Workers in the High Technology and Financial Services Industries". International Journal of Human Resource Management, 12(7): 1152-1165.

FREEMAN, R. E. \& STEWART, L. (2006). "Developing Ethical Leadership”. Bridge Papers. Business Roundtable Institute for Corporate Ethics. http://www.inexlibris.com/Articles/download/eadcb623-1da5-42c6-a02a00bfacabd48b/, 25.08.2020. 
FRY, L. \& KRIGER, M. (2009). "Towards a theory of being-centered leadership: Multiple levels of being as context for effective leadership". Human Relations, 62(11): 16671696.

GAGNE, M. (2009). “A model of knowledge-sharing motivation”. Human Resource Management, 48(4): 571-589.

GOSWAMI, A.K. \& AGRAWAL, R.K. (2018). “A reflection on knowledge sharing research: patterns and trends". VINE Journal of Information and Knowledge Management Systems, 48(3): 352-372.

GÖKSEL, A. \& AYDINTAN, B. (2017). "How can tacit knowledge be shared more in organizations? A multidimensional approach to the role of social capital and locus of control". Knowledge Management Research \& Practice, 15(1): 34-44.

HAN, S. H., SEO, G., YOON, S. W. \& YOON, D. Y. (2016). “Transformational leadership and knowledge sharing: Mediating roles of employee's empowerment, commitment, and citizenship behaviors". Journal of Workplace Learning, 28(3): 130-149.

HASSAN, S., MAHSUD, R., YUKL, G. \& PRUSSIA, G. E. (2013). "Ethical and empowering leadership and leader effectiveness". Journal of Managerial Psychology, 28(2): 133146.

HSU, M. H., JU, T. L., YEN, C. H. \& CHANG, C. M. (2007). "Knowledge sharing behavior in virtual communities: The relationship between trust, self-effi cacy, and outcome expectations". International Journal of Human-Computer Studies, 65(2): 153-169.

IPE, M. (2003). "Knowledge sharing in organizations: A conceptual framework". HRM Development Review, 2: 337-359.

IŞIK, M. (2018). "Bilgi paylaşımını etkileyen faktörler ve bilgi paylaşım sürecinin yenilikçi iş davranışına etkisi”. Uluslararası İktisadi ve İdari İncelemeler Dergisi, 17. UİK Özel Sayıs1, 641-656.

JAIN, K. K., SANDHU, M. S. \& GOH, S. K. (2015). "Organizational climate, trust and knowledge sharing: insights from Malaysia”. Journal of Asia Business Studies, 9(1): 5477.

JAVED, B., KHAN, A. A., BASHIR, S. \& ARJOON, S. (2017). "Impact of ethical leadership on creativity: the role of psychological empowerment". Current Issues in Tourism, 20(8): 839-851.

JAVED, B., RAWWAS, M., KHANDAI, S., SHAHID, K., \& TAYYEB, H. (2018). "Ethical leadership, trust in leader and creativity: The mediated mechanism and an interacting effect". Journal of Management \& Organization, 24(3): 388-405.

JOHNSON, K. W. (2005). "The role of leadership in organizational integrity and five modes of ethical leadership". Ethical Leadership, EPIC-Online.net, 1-9.

JORDAN, J., BROWN, M. E., TREVINO, L. K. \& FINKELSTEIN, S. (2013). "Someone to look up to: Executive-follower ethical reasoning and perceptions of ethical leadership". Journal of Management, 39(3), 660-683. 
KALSHOVEN, K., Den HARTOG, D. N. \& De HOOGH, A. H. B. (2013). “Ethical leadership and followers' helping and initiative: The role of demonstrated responsibility and job autonomy". European Journal of Work and Organizational Psychology, 22(2): 165-181.

KANUNGO, R. N. \& MENDONCA, M. (1996). Ethical Dimensions of Leadership, Sage Publications, Series in Business Ethics, Thousand Oaks.

KITCHENHAM, B. (2004). "Procedures for performing systematic reviews". Keele University, Newcastle, 33: 1-26.

LAM, A. (2000). "Tacit knowledge, organizational learning and societal institutions: An integrated framework". Organization Studies, 21(3): 487-513.

LE, P. B. \& LEI, H. (2018). "Fostering knowledge sharing behaviours through ethical leadership practice: the mediating roles of disclosure-based trust and reliance-based trust in leadership". Knowledge Management Research \& Practice, 16(2): 183-195.

LENGNICK-HALL, M. L. \& LENGNICK-HALL, C. A. (2003). Human Resource Management in the Knowledge Economy: New Challenges, New Roles, New Capabilities, Berrett-Koehler, San Francisco, CA.

LIN, C. P. (2007a). "To Share or Not to Share: Modeling Tacit Knowledge Sharing, Its Mediators and Antecedents". Journal of Business Ethics, 70: 411-428.

LIN, C. P. (2007b). "To share or not to share: Modeling knowledge sharing using exchange ideology as a moderator". Personnel Review, 36(3): 457-475.

LIN, C. P. (2008). "Clarifying the relationship between organizational citizenship behaviors, gender, and knowledge sharing in workplace organizations in taiwan. Journal of Business and Psychology, 22: 241-250.

LIN, H. F. (2007). "Knowledge sharing and firm innovation capability: An empirical study". International Journal of Manpower, 28(3/4): 315-332.

LOWENDAHL, B. R., REVANG, O. \& FOSSTENLOKKEN, S. M. (2001). "Knowledge and value creation in Professional service firms: A framework for analysis". Human Relations, 54(7): 911-931.

MA, Y., CHENG, W., RIBBENS, B. A., \& ZHOU, J. (2013). "Linking ethical leadership to employee creativity: Knowledge sharing and self efficacy as mediators". Social Behavior and Personality: An International Journal, 41(9): 1409-1419.

MADENOĞLU, C., UYSAL, Ş., SARIER, Y. \& BANOĞLU, K. (2014). “Okul Müdürlerinin Etik Liderlik Davranışları ile Öğretmenlerin İş Doyumlarının Örgütsel Bağlılıkla İlişkisi”. Kuram ve Uygulamada Eğitim Yönetimi Dergisi, 20(1): 47-69.

MASA'DEH, R., OBEIDAT, B.Y. \& TARHINI, A. (2016). “A Jordanian empirical study of the associations among transformational leadership, transactional leadership, knowledge sharing, job performance, and firm performance: A structural equation modelling approach”. Journal of Management Development, 35(5): 681-705. 
MASOOD, K. (2020). "Ethical leadership and knowledge management behaviors: role of organizational citizenship behavior and procedural justice". International Journal of Science and Business, 4(3): 56-69.

MAYER, D. M., KUENZI, M., GREENBAUM, R., BARDES, M. \& SALVADOR, R. B. (2009). "How low does ethical leadership flow? Test of a trickle-down model". Organizational Behavior and Human Decision Processes, 108(1): 1-13.

MEN, C., FONG, P. S., HUO, W., ZHONG, J., JIA, R. \& LUO, J. (2018). “Ethical leadership and knowledge hiding: a moderated mediation model of psychological safety and mastery climate". Journal of Business Ethics, 166: 461-472.

MIHELIC, K. K, LIPICNIK, B. \& TEKAVCIC, M. (2010). “Ethical Leadership”. International Journal of Management \& Information Systems. Fourth Quarter, 14(5): 31-42.

MOHER, D., LIBERATI, A., TETZLAFF, J. \& ALTMAN, D.G. (2009). "Preferred reporting items for systematic reviews and meta-analyses: the PRISMA statement". Journal of Clinical Epidemiology, 62(10): 1006-1012.

NEUBERT, M. J., CARLSON, D. S., KACMAR, K. M., ROBERTS, J. A. \& CHONKO, L. B. (2009). "The virtuous influence of ethical leadership behavior: Evidence from the field". Journal of Business Ethics, 90: 157-170.

NONAKA, I. (1994). “A Dynamic Theory of Organizational Knowledge Creation”. Organization Science, 5(1): 14-37.

NONAKA, I., von KROGH, G. \& VOELPEL, S. (2006). “Organizational knowledge creation theory: Evolutionary paths and future advances". Organization Studies, 27(8): 11791208 .

NORTHOUSE, P. G. (2007). Leadership Theory and Practice, 4. Bask1, Sage Publications, Thousand Oaks.

O’NEILL, B. S. \& ADYA, M. (2007). "Knowledge sharing and the psychological contract”. Journal of Managerial Psychology, 22(4): 411-436.

ÖZDAŞLI, K. \& DERYA, S. (2011). Etik ve Etiğe İlişkin Temel Kavramlar. Zeyyat Sabuncuoğlu (Eds.), İşletme Etiği (67-84). Beta Yayınları, İstanbul.

ÖZSUNGUR, F. (2019). “The impact of ethical leadership on service innovation behavior: The mediating role of psychological capital”. Asia Pacific Journal of Innovation and Entrepreneurship, 13(1): 73-88.

PARK, H., RIBIERE, V. \& SCHULTE, W. D. (2004). “Critical attributes of organizational culture that promote knowledge management technology implementation success". Journal of Knowledge Management, 8(3): 106-117.

PICCOLO, R. F., GREENBAUM, R., Den HARTOG, D. N. \& FOlGER, R. (2010). “The Relationship between Ethical Leadership and Core Job Characteristics". Journal of Organizational Behavior, 31(2-3): 259-278. 
QIAN, J., WANG, B., HAN, Z. \& SONG, B. (2017). "Ethical Leadership, Leader-Member Exchange and Feedback Seeking: A Double-Moderated Mediation Model of Emotional Intelligence and Work-Unit Structure”. Frontiers Psychology. 8(1174): 1-11.

QIAN, Y.\& JIAN, G. (2020). "Ethical leadership and organizational cynicism: the mediating role of leader-member exchange and organizational identification". Corporate Communications: An International Journal, 25(2): 207-226.

QUiGLEY, N. R., TESLUK, P. E., LOCKE, E. A. \& BARTOL, K. M. (2007). “A multilevel investigation of the motivational mechanisms underlying knowledge sharing and performance". Organization, 18(1): 71-88.

RAHAMAN, H. M. S., STOUTEN, J. \& GUO, L. (2019). “Antecedents of ethical leadership: the theory of planned behavior". Leadership \& Organization Development Journal, 40(6): 735-746.

RESICK, C. J., HANGES, P. J., DICKSON, M. W. \& MITCHELSON, J. K. (2006). “A crosscultural examination of the endorsement of ethical leadership". Journal of Business Ethics, 63: 345-359.

RESICK, C. J., MARTIN, G. S., KEATING, M. A., DICKSON, M. W., KWAN, H. K. \& PENG, C. (2011). "What ethical leadership means to me: Asian", American, and European perspectives. Journal of Business Ethics, 101(3): 435-457.

SCHAUBROECK, J. M., HANNAH, S. T., AVOLIO, B. J., KOZLOWSKI, S. W., LORD, R. G., TREVINO, L. K., DIMOTAKIS, N. \& PENG, A. C. (2012). "Embedding Ethical Leadership Within and Across Organization Levels". Academy of Management Journal, 55(5): 1053-1078.

SHAFIQUE, I., AHMAD, B. \& KALYAR, M. N. (2019). "How ethical leadership influences creativity and organizational innovation: Examining the underlying mechanisms". European Journal of Innovation Management, 23(1): 114-133.

SHARIFKHANI, M., KHAZAEI POOL, J. \& ASIAN, S. (2016). "The impact of leadermember exchange on knowledge sharing and performance: An empirical investigation in the oil and gas industry". Journal of Science and Technology Policy Management, 7(3): 289-305.

SHARMA, A., AGRAWAL, R. \& KHANDELWAL, U. (2019). "Developing ethical leadership for business organizations: A conceptual model of its antecedents and consequences”. Leadership \& Organization Development Journal, 40(6): 712-734.

SONG, S. (2001). "An internet knowledge sharing system". The Journal of Computer Information Systems, 42(3): 25-30.

SRIVASTAVA, A., BARTOL, K. M. \& LOCKE, E. A. (2006). "Empowering leadership in management teams: Effects on knowledge sharing, efficacy, and performance". Academy of Management Journal, 49(6): 1239-1251.

SUBBA, D. (2019). “Antecedent and consequences of organizational identification: a study in the tourism sector of Sikkim". Future Business Journal, 5(4): 1-9. 
TAN, L. P., YAP, C. S., CHOONG, Y. O., CHOE, K. L., RUNGRUANG, P. \& LI, Z. (2019). "Ethical leadership, perceived organizational support and citizenship behaviors: The moderating role of ethnic dissimilarity". Leadership \& Organization Development Journal, 40(8): 877-897.

TANG, P. M., BAVIK, Y. L., CHEN, Y. F. \& TJOSVOLD, D. (2015). "Linking ethical leadership to knowledge sharing and knowledge hiding: The mediating role of psychological engagement". International Proceedings of Economics Development and Research, 84: 71-76.

TANNER, C., BRUGGER, A., van SCHIE, S. \& LEBHERZ, C. (2010). “Actions speak louder than words: The benefits of ethical behaviors of leaders". Journal of Psychology, 218(4): 225-233.

TEH, P. \& SUN, H. (2012). “Knowledge sharing, job attitudes and organisational citizenship behaviour". Industrial Management \& Data Systems, 112(1): 64-82.

TREVINO, L. K. \& BROWN, M. E. (2004). "Managing to be Ethical: Debunking five Business Ethics Myths". Academy of Management Executive, 18(2): 69-81.

TREVINO, L. K., BROWN, M. \& HARTMAN, L. P. (2003). “A qualitative investigation of perceived executive ethical leadership: Perceptions from inside andoutside the executive süite”. Human Relations, 56(1): 5-37.

TREVINO, L. K., HARTMAN, L. P. \& BROWN, M. E. (2000). "Moral Person And Moral Manager: How Executive Develop A Reputation For Ethical Leadership". California Management Review, 42(4): 128-142.

TU, Y. ve LU, X. (2016). "Do ethical leaders give followers the confidence to go the extra mile? the moderating role of intrinsic motivation". Journal of Business Ethics, 135: 129144.

Van Den HOOFF, B. \& De RIDDER, J. A. (2004). "Knowledge sharing in context: The influence of organizational commitment, communication climate, and CMC use on knowledge sharing”. Journal of Knowledge Management, 8(6): 117-130.

WALUMBWA, F. O. \& SCHAUBROECK, J. (2009). "Leader personality traits and employee voice behavior: mediating roles of ethical leadership and work group psychological safety". Journal of Applied Psychology, 94(5): 1275-1286.

WALUMBWA, F. O., MAYER, D. M., WANG, P., WANG, H., WORKMAN, K. \& CHRISTENSEN, A. L. (2011). "Linking ethical leadership to employee performance: The roles of leader-member exchange, self-efficacy, and organizational identification". Organizational Behavior and Human Decision Processes, 115(2): 204-213.

WANG, C. (2004). "The influence of ethical and self-interest concerns on knowledge sharing intentions among managers: An empirical study". International Journal of Management, 21(3): 370-381.

WANG, S. \& NOE, R. A. (2010). "Knowledge sharing: a review and directions for future research". Human Resource Management Review, 20(2): 115-131. 
WANG, Z. \& WANG, N. (2012). "Knowledge sharing, innovation and firm performance". Expert Systems With Applications, 39(10): 8899-8908.

WRIGHT, T. A. \& QUICK, J. C. (2011). "The role of character in ethical leadership research". The Leadership Quarterly, 22(5): 975-978.

YANG, H., van RIJN, M.B. \& SANDERS, K. (2020). "Perceived organizational support and knowledge sharing: employees' self-construal matters". The International Journal of Human Resource Management, 31(17): 2217-2237.

YANG, J. T. (2008). “Individual Attitudes and Organisational Knowledge Sharing”. Tourism Management. 29(2): 345-353.

ZEB, A., ABDULlAH, N.H., HUSSAIN, A. \& SAFI, A. (2019). “Authentic leadership, knowledge sharing, and employees' creativity”. Management Research Review, 43(6): 669-690.

ZHAO, H. \& XIA, Q. (2019). "Nurses' negative affective states, moral disengagement, and knowledge hiding: the moderating role of ethical leadership". Journal of Nursing Management, 27(2): 357-370.

ZHAO, L., DETLOR, B. \& CONNELLY, C. (2016). "Sharing knowledge in social Q\&A sites: The unintended consequences of extrinsic motivation". Journal of Management Information Systems, 33(1): 70-100.

ZHOU H., JIN, M. \& MA, Q. (2015). "Remedy for work stress: the impact and mechanism of ethical leadership”. Central European Journal of Public Health, 23(2): 176-180.

ZHU, W., MAY, D.R. \& AVOLIO, B.J. (2004). “The Impact of Ethical Leadership Behavior on Employee Outcomes: The Roles of Psychological Empowerment and Authenticity". Journal of Leadership \& Organizational Studies, 11(1): 16-26.

ZHU, W., RIGGIO, R. E., AVOLIO, B. J. \& SOSIK, J. J. (2011). “The effect of leadership on follower moral identity: Does transformational/transactional style make a difference?" Journal of Leadership and Organizational Studies, 18(2): 150-163. 